\title{
Antarctic new particle formation from continental biogenic precursors
}

\author{
E.-M. Kyrö ${ }^{1}$, V.-M. Kerminen ${ }^{1}$, A. Virkkula ${ }^{1,2}$, M. Dal Maso ${ }^{1,3}$, J. Parshintsev ${ }^{4}$, J. Ruíz-Jimenez ${ }^{4}$, L. Forsström ${ }^{5}$, \\ H. E. Manninen ${ }^{1}$, M.-L. Riekkola ${ }^{4}$, P. Heinonen ${ }^{6}$, and M. Kulmala ${ }^{1}$ \\ ${ }^{1}$ Department of Physics, University of Helsinki, Helsinki, Finland \\ ${ }^{2}$ Air Quality Research, Finnish Meteorological Institute, Helsinki, Finland \\ ${ }^{3}$ Department of Physics, Tampere University of Technology, Tampere, Finland \\ ${ }^{4}$ Department of Chemistry, University of Helsinki, Helsinki, Finland \\ ${ }^{5}$ Department of Biological and Environmental Sciences, University of Helsinki, Helsinki, Finland \\ ${ }^{6}$ FINNARP logistics, Finnish Meteorological Institute, Helsinki, Finland
}

Correspondence to: E.-M. Kyrö (ella-maria.kyro@helsinki.fi)

Received: 6 November 2012 - Published in Atmos. Chem. Phys. Discuss.: 19 December 2012

Revised: 1 March 2013 - Accepted: 7 March 2013 - Published: 2 April 2013

\begin{abstract}
Over Antarctica, aerosol particles originate almost entirely from marine areas, with minor contribution from long-range transported dust or anthropogenic material. The Antarctic continent itself, unlike all other continental areas, has been thought to be practically free of aerosol sources. Here we present evidence of local aerosol production associated with melt-water ponds in continental Antarctica. We show that in air masses passing such ponds, new aerosol particles are efficiently formed and these particles grow up to sizes where they may act as cloud condensation nuclei $(\mathrm{CCN})$. The precursor vapours responsible for aerosol formation and growth originate very likely from highly abundant cyanobacteria Nostoc commune (Vaucher) communities of local ponds. This is the first time freshwater vegetation has been identified as an aerosol precursor source. The influence of the new source on clouds and climate may increase in future Antarctica, and possibly elsewhere undergoing accelerating summer melting of semi-permanent snow cover.
\end{abstract}

\section{Introduction}

Antarctica is experiencing dramatic changes especially in the peninsula and western part but also in the coastal areas around the whole continent (Chen et al., 2009; Pritchard et al., 2009). These are also the areas with most of the continents exposed ground and high mountains. Especially the spring temperatures have been increasing in these areas (Steig et al., 2009; Schneider et al., 2012) followed by increasing ice mass loss (Pritchard et al., 2009) and ice shelf collapses (Rignot et al., 2004). In spring and summer, intense solar radiation melts snow and ice around the mountains, as well as areas with exposed ground and blue ice, into ponds and lakes. The increasing temperature decreases the overall surface albedo in these areas by enhancing the snow and ice melt (Hall, 2004).

The Antarctic climate system is coupled tightly with aerosol particles via global warming and associated feedback processes involving aerosol-cloud interactions. The most studied aerosol type in this respect is the natural sulphate aerosol originating from oceanic dimethyl sulphide (DMS) emissions affected mainly by ocean biochemistry and wind speed (Korhonen et al., 2008). Another prominent aerosol type over Antarctica is sea salt (Shaw, 1988; Hara et al., 2011; Weller et al., 2011), the concentration and properties of which are influenced by the sea ice extent, wind speed and probably also by the sea water temperature (Struthers et al., 2011). In addition to these two natural aerosol types, small amounts of dust and anthropogenic pollution-derived particles are occasionally long-range transported to Antarctica (Shaw, 1988; Fiebig et al., 2009). The Antarctic continent has been thought to be a weak source of primary aerosol particles, mainly dust as well as pollen and bacteria 
(Gonzáles-Toril et al., 2009), and a negligible source of precursors for secondary aerosol particles.

Here, we investigate secondary aerosol formation observed during the Finnish Antarctic Research Program (FINNARP) 2009 expedition at the Finnish Antarctic Research Station Aboa. Previous studies have shown that secondary Antarctic aerosols originate from oceanic DMS emissions (O'Dowd et al., 1997; Davis et al., 1998; Asmi et al., 2010; Yu and Luo, 2010), long-range transport (Ito, 1993; Fiebig et al., 2009; Hara et al., 2011), or from intrusion of upper tropospheric air into the boundary layer (Virkkula et al., 2009). Also local anthropogenic sources have been linked with new particle formation (NPF) in continental Antarctica (Park et al., 2004). At Aboa, the particle formation mostly takes place in air masses coming along the coastline (Koponen et al., 2003) or intruding from higher altitude (Virkkula et al., 2009). Observations of growth of the smallest cluster ions suggest that the nucleation can occur even in the boundary layer (Asmi et al., 2010). It has also been suggested that secondary organic matter, having a significant contribution in the Aitken and accumulation modes, could contribute to the growth of aerosol particles (Virkkula et al., 2006, 2009). However, observations of nanometer-sized secondary organic aerosols have not been made over Antarctica.

Our principal goal in this paper is to find out the origin of secondary aerosol particles and their precursors in the summer continental Antarctic atmosphere. In addition to this, we aim to explore which vapours make the newly formed particles grow in size, and whether Antarctic secondary aerosol formation is capable of producing cloud condensing nuclei.

\section{Materials and methods}

\subsection{Description of the site and measurements}

The aerosol and atmospheric composition measurements discussed here were carried out between 8 December 2009 and 23 January 2010 at the Finnish Antarctic Research Station, Aboa (location is shown in Asmi et al., 2010), in Dronning Maud Land, during the FINNARP 2009 expedition. The station is built on a nunatak Basen, approximately $500 \mathrm{~m}$ above sea level and some $130 \mathrm{~km}$ away from the open ocean in summer. During the summer, snow and ice on top of Basen melts into biologically active, shallow ponds. The most abundant macroscopic organism in these ponds is cyanobacteria Nostoc commune (Vaucher). The majority of the ponds during FINNARP 2009 expedition were approximately $2 \mathrm{~km}$ from the measurement site. The measurement site is located $200 \mathrm{~m}$ upwind from the main building. Since winds blow most of the time from the north-east, contamination by the station and vehicles that are used at the main station is minimal. We measured aerosols continuously at about $3 \mathrm{~m}$ above the ground level. The total particle number size distribution in the diameter range $10-500 \mathrm{~nm}$ was measured using a differential mobility particle sizer (DMPS), and the size distributions of positively and negatively charged particles in the diameter range $0.8-42 \mathrm{~nm}$ were measured using an air ion spectrometer (AIS). In order to get information on the aerosol chemical composition, particles were collected on quartz filters and the filters were changed three times a week. Methanolic extracts obtained from the filter samples after ultrasoundassisted extraction were analyzed later in Finland using a comprehensive two-dimensional gas chromatography-timeof-flight mass spectrometer (GCxGC-TOF-MS). In addition, samples from the cyanobacterial mats and water were taken and analysed.

\subsection{Measurement setup and equipment}

The measurements of neutral and charged particle size distributions, ozone concentration and chemical filter samples were carried out during the FINNARP 2009 expedition. All the devices were kept inside a small container, about $200 \mathrm{~m}$ upwind from the main station, as described by Virkkula et al. (2007) and Asmi et al. (2010). The inlets were approximately $3 \mathrm{~m}$ above the ground. For the DMPS and the filter sampling, a $25 \mathrm{~mm}$ inlet with flow splitter with no sectorcontrol was used. A separate $35 \mathrm{~mm}$ copper inlet was used for the AIS and for the ozone monitor, a $6 \mathrm{~mm}$-wide teflon tube was used as an inlet.

\subsubsection{Air ion spectrometer}

Measuring the ion concentration and charge distribution of aerosol particles offers an effective method to study particle formation mechanisms. In this campaign the ion spectrometer was the only instrument able to measure directly the early stages of atmospheric nucleation and subsequent growth. New particle formation event analysis, including event classification and formation and growth rate calculations for ion spectrometer data, already has well-defined guidelines (Hirsikko et al., 2005; Manninen et al., 2010; Kulmala et al., 2012). The air ion spectrometer (AIS) (Mirme et al., 2007) measures the mobility distributions of both negative and positive air ions simultaneously in the range between 3.2 and $0.0013 \mathrm{~cm}^{2} \mathrm{~V}^{-1} \mathrm{~s}^{-1}$, which corresponds to a mobility diameter range of $0.8-42 \mathrm{~nm}$. The mobility diameter, i.e. the Millikan diameter, is applied when converting the measured mobility to the particle diameter (Mäkelä et al., 2006). The AIS consists of two parallel cylindrical DMAs (Differential Mobility Analyzer), one for classifying negative ions and the other for positive ions. The ions are simultaneously classified according to their electrical mobility with differential radial electric field and collected to 21 electrically isolated sections. Each section has its own electrometer to measure the currents carried by the ions. The total flow into the AIS is $60 \mathrm{~L} \mathrm{~min}^{-1}$, whereas the sample and the sheath flows of the DMAs are 30 and $60 \mathrm{~L} \mathrm{~min}^{-1}$, respectively. 


\subsubsection{Differential Mobility Particle Sizer}

The differential mobility particle sizer (DMPS) (Aalto et al., 2001) setup measures atmospheric aerosol particle number size distribution between 10 and $700 \mathrm{~nm}$ in diameter. The DMPS consists of Hauke-type DMA (28.0 cm long), CPC (Condensation Particle Counter) (TSI 3772) as a particle detector, closed-loop sheath flow arrangement and radioactive carbon-14 beta neutralizer. The sample flow rate is $1 \mathrm{~L} \mathrm{~min}^{-1}$ and the sheath flow rate is $10 \mathrm{~L} \mathrm{~min}^{-1}$; both were checked regularly with a bubble flowmeter. The complete size distribution is obtained in a $6 \mathrm{~min}$ time resolution by changing the classifying voltage of the DMA. The total aerosol number concentration is calculated from the measured number size distribution.

\subsubsection{Filter sampling}

The filter sampling was taken from the same sampling line as for the DMPS. The filters that were used were quartz, $47 \mathrm{~mm}$ in diameter (Whatman International, Kent, UK). The flow rate was first $50 \mathrm{~L} \mathrm{~min}^{-1}$ but later (7 January 2010 onwards) it was changed into $25 \mathrm{~L} \mathrm{~min}^{-1}$. No cut-off was used in the inlet. Filters were stored in petri slides under a laminar flow hood inside the measurement container at room temperature.

\subsubsection{Ozone analyzer}

A continuous ozone analyzer O342M by Environnement S.A was used to monitor the ozone concentrations. The analyzer was calibrated before the campaign at an accredited calibration laboratory at the Finnish Meteorological Institute (FMI). The ozone concentration is detected by the difference in ultraviolet absorption between ambient air and ozone-cleaned sample. One measurement cycle takes approximately $10 \mathrm{~s}$.

\subsubsection{Cyanobacterial mat and water samples}

Samples from the ponds and cyanobacterial mats were taken on 3 January 2010 . Two $50 \mathrm{~mL}$ bottles were cleaned thoroughly with ethanol. One bottle was filled with water taken from the pond and another one with the water-Nostoc commune mixture. The samples were taken from the same pond on the top of Basen. The size of the pond was approximately $40 \mathrm{~m}^{2}$ and it was $10-20 \mathrm{~cm}$ deep. Many similar ponds were found from the nunatak, the largest one being more than $100 \mathrm{~m}^{2}$ in area. The bottles were stored in a freezer and transported to Finland in a frozen container.

\subsection{Analysis of aerosol size distribution measurement}

NPF events can be visually classified based on the shape of the particle size distribution into different types (Dal Maso et al., 2005; Yli-Juuti et al., 2009; Manninen et al., 2010; Kulmala et al., 2012). The different types of events are signatures of NPF happening on different spatial and temporal scales and their shape is caused by the Eulerian way of measuring the air mass. Traditional "banana" events are typically observed when NPF happens over a geographically large area. A "banana" event appears in the size distribution as a wide band which starts from the lower limit of the size distribution and curves smoothly towards higher sizes. This kind of appearance requires formation and growth that lasts over several hours or even days. Other types (e.g. "apple", "bump" and "wind-induced", all of which were observed at Aboa during FINNARP 2009 expedition) represent more local NPF. Common for each of these is that they appear as round- or obscure-shaped short-time increases in particle concentration in the lowest particle sizes. Due to their shape, it is not possible to obtain growth rate for these events.

The rate at which the newly formed aerosol population grows (i.e. particle growth rate, GR) can be determined from the measured number size distributions by following the geometric mean size of the nucleation mode particles (Dal Maso et al., 2005; Yli-Juuti et al., 2011; Kulmala et al., 2012). The GR can be reliably determined only for "banana"type events. Size-distribution-dependent particle losses can be characterized by condensation and coagulation sinks (CS and CoagS, respectively) (Kulmala et al., 2001, 2012; Dal Maso et al., 2002). The CS is a value of how rapidly vapour molecules will condense onto pre-existing aerosol, whereas CoagS determines how rapidly aerosol particles are removed through coagulation scavenging. CS is dependent on the effective surface area of the particles and pre-existing size distribution, whereas CoagS is a function of the diameter of the scavenged particle and pre-existing size distribution (Lehtinen et al., 2007). Thus, essentially they represent the same phenomenon, but the one (CS) is for gases and the other (Co$\mathrm{agS}$ ) for particles.

The formation rate of particles of certain size $(J)$ is calculated by taking into account the time evolution of the particle number concentration and the losses due to coagulation scavenging to the larger pre-existing particles as well as the growth out of the size range (Manninen et al., 2010; Kulmala et al., 2012). For charged particles, the losses due to ion-ion recombination and sources due to charging of the particles need to be also addressed (Manninen et al, 2010).

\subsection{Chemical analysis}

\subsubsection{Filter samples: elucidication of the aerosol particle components}

A comprehensive two-dimensional gas chromatographtime-of-flight mass spectrometer (GCxGC-TOF-MS) from LECO (LECO Instrument Ltd., Stockport, Chesire, England) was used for the elucidation of volatile and semivolatile organic compounds in aerosol particles. The methodology used for the extraction, derivatisation, individual isolation and identification of the compounds was similar to that reported earlier (Ruiz-Jimenez et al., 2011a, b). Briefly, 
the compounds were extracted from the filters by sonication assisted extraction. Samples with and without derivatisation were analysed in triplicate. The derivatisation step was necessary to increase the volatility of the semivolatile and low-volatile compounds. $50 \mathrm{ng}$ of 2,4-dichlorobenzoic acid, used as internal standard (IS) for the derivatisation step, was added to the sample before the derivatisation. Sample solvent was then evaporated with a gentle stream of nitrogen. A mixture of $20 \mu \mathrm{L}$ of BSTFA (N, O-bis(trimethylsilyl)trifluoroacetamide) containing $1 \%$ of TMCS (trimethylchlorosilane) and $20 \mu \mathrm{L}$ of pyridine was used as a derivatisation reagent. The reaction was accelerated by the application of ultrasound for $30 \mathrm{~min}$ at $35^{\circ} \mathrm{C}$. Before GCxGC-TOF-MS analysis, $5 \mathrm{ng}$ of 1-1'-binaphthyl, used as IS for the injection, was added. In a third step, the most compounds present in the extract were individually isolated and detected using the GCxGC-TOF-MS. The identification was based on the comparison of the spectral information obtained from the detector and the retention indexes calculated using authentic standards with the information provided by $\mathrm{Na}-$ tional Institute of Standards and Technology and the Golm databases. Identified compounds were classified into seven groups according to their chemical composition: hydrocarbons, halogenated compounds, nitrogen compounds, sulphur compounds, carboxyl, carbonyl and hydroxyl compounds.

The high number of identified compounds in GCxGCTOF-MS made the quantitation a challenging task. The semiquantitation of the identified compounds was achieved in this research using the normalized response factor (NRF), calculated as follows:

$\mathrm{NRF}=\sum \mathrm{NRF}_{i}=\sum \frac{A C_{i}}{A_{\mathrm{IS}}}$,

where $A C_{i}$ is the peak area of the different analytes and $A_{\mathrm{IS}}$ is the peak area obtained for 1-1'-binaphthyl, used as the internal standard for the injection.

An average of 261 compounds per sample were identified using the proposed methodology. The classification of these compounds into the different chemical groups (Fig. 1) revealed that hydrocarbons, carboxyl and hydroxyl compounds are the families which contain most of the compounds. The classification was done in two steps: first the identified compounds were classified in a sequential and exclusive way as a function of their elemental composition. After this, the oxygenated compounds $(\mathrm{C}, \mathrm{H}$ and $\mathrm{O})$ were classified into carboxyl, carbonyl and or hydroxyl compounds in agreement with the highest oxidation state of the functional groups present in the molecules.

\subsubsection{Samples from water and Nostoc commune}

Samples 1 (only water) and 2 (water with small pieces of cyanobacteria) were taken from the freezer $20 \mathrm{~min}$ before the extraction. $5 \mathrm{~mL}$ of sample was subjected two times to liquid-liquid extraction (LLE) with $5 \mathrm{~mL}$ dichloromethane as

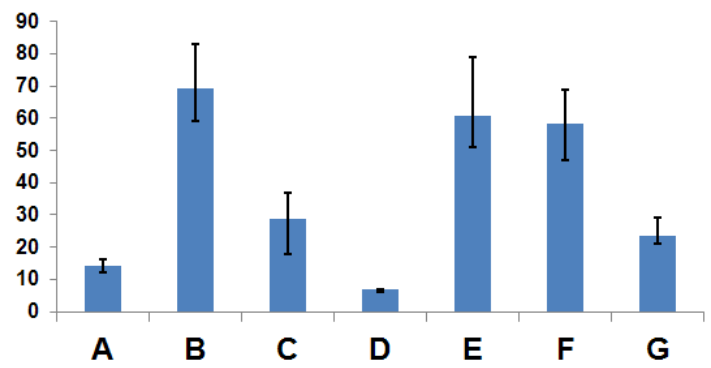

Fig. 1. Classification of compounds found in the quartz filter samples into main chemical groups. (A) Halogenated compounds, (B) hydrocarbons, (C) nitrogen compounds, (D) sulphur compounds, (E) carboxyl compounds, (F) hydroxyl compounds and (G) carbonyl compounds. The y-axis is the number of detected compounds.

such (a) or after $\mathrm{pH}$ adjustment $(100 \mu \mathrm{L}$ of $1 \mathrm{M} \mathrm{HCl})(\mathrm{b})$. Zero samples were made from distilled water (same treatment as real samples). Sample 3 (pieces of cyanobacteria, $142.7 \mathrm{mg}$ fresh weight) was extracted by static ultrasound assisted extraction with $10 \mathrm{~mL}$ of acetone $(30 \mathrm{~min})$ as a solvent (Kallio et al., 2006) and filtered through $0.45 \mu \mathrm{m}$ syringe filter. Volume of all samples was reduced to $5 \mathrm{~mL}$ by evaporation with gentle stream of nitrogen without heating. Two aliquots of $1.5 \mathrm{~mL}$ were taken from each sample for the further analysis. The sample preparation before the injection to GCxGCTOF-MS was identical with that used in the case of the filter samples. In total, 135 and 227 compounds were identified from water (sample 1 and 2) and algae (sample 3) samples, respectively.

\section{Results and discussion}

During the campaign, three new particle formation (NPF) event periods were observed (Fig. 2, upper panel). In the first event period, 9 to 11 December 2009, the intensity of NPF was however very low, and occurred during an intrusion of air from higher altitudes. This could be seen as an increase in the ozone concentration at the measurement site, but also in the HYSPLIT back trajectories. The next two NPF periods were much more intense compared to the first event period. In the following discussion we will focus on these two periods.

The total particle concentration (contamination not taken into account) during the campaign was on average several hundreds of particles per $\mathrm{cm}^{3}$, while during the event periods it increased to several thousands of particles per $\mathrm{cm}^{3}$ (Fig. 2, second panel). The highest concentrations were observed during the second event period (1 to 3 January 2010).

Some compounds that were found from both cyanobacterial mat and water samples as well as filter samples were present only during the second event period ( 1 to 3 January 2010), whereas some were enhanced during all event periods 


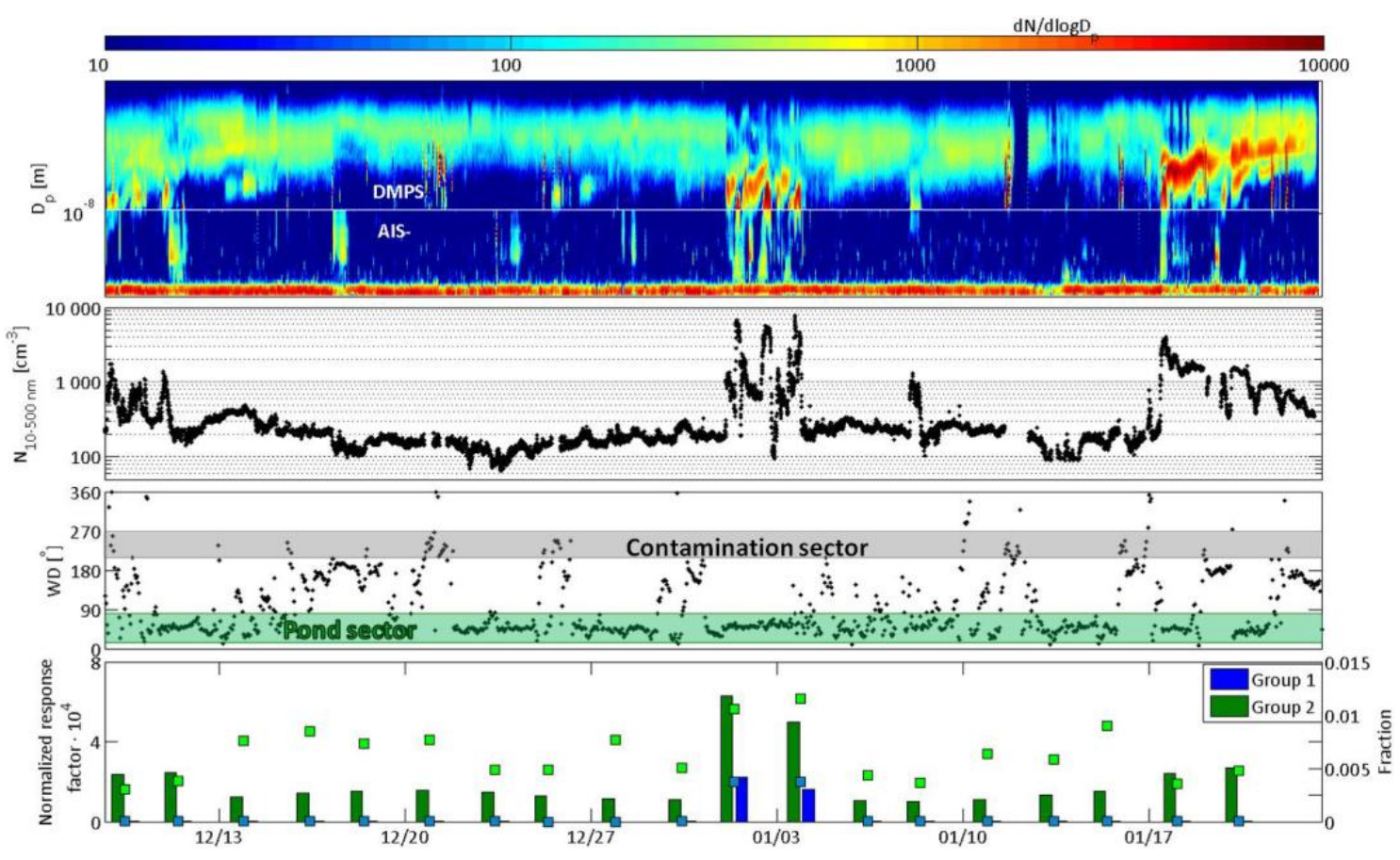

Fig. 2. The negatively charged $(0.8-10 \mathrm{~nm})$ and neutral particle $(10-500 \mathrm{~nm})$ number size distribution (upper panel) during the campaign, 8 December 2009 to 23 January 2010 (the time axis is the same in every figure). The total particle concentration, where the contamination has been taken away, is given in the second panel. The third panel shows the wind direction at $1 \mathrm{~h}$ time resolution with the pond and contamination sectors shaded with green and grey, respectively. The lowermost panel shows the normalized response factor (bars) of Group 1 and Group 2 compounds as well as their fraction from all detected organic compounds (coloured rectangles).

(Fig. 2). These were called Group 1 and Group 2, respectively. Also, the relative fraction of Group 2 compounds was greatest during the second event period.

\subsection{Overview of the observed nucleation events}

During the event periods 1 to 3 January 2010 and 17 to 20 January 2010, apple- and bump-type as well as banana-type new particle formations were observed. These different types of events are signatures of NPF occurring on different spatial scales (Manninen et al., 2010; Kulmala et al., 2012). Appletype new particle formation is commonly considered to be a signature of particle formation on a local scale, with formation occurring fairly close to the observation point (O'Dowd et al., 2002; Manninen et al., 2010). Due to the proximity of the observation point and the fresh particle source area, there is insufficient time for observable particle growth to occur. During each local NPF event, the local wind direction was from the pond sector. Banana-type new particle formation is considered to represent particle formation and growth on a regional scale (Dal Maso et al., 2007; Manninen et al., 2010). In this type of observation, the air mass during the event is considered to be fairly homogeneous, with particle formation and subsequent growth occurring throughout the advecting air mass for the duration of the observed event.

\subsubsection{Event period 1 to 3 January 2010}

During the event period 1 to 3 January 2010, four local and three regional NPF events were observed (Fig. 3). The period started with rapid increase in both wind speed and temperature in the early hours of New Year Day. The air mass change is very clear from the surface plot (second panel, Fig. 3), as a new mode appeared rapidly around 02:00 UTC. During the period, solar radiation was always available and the wind blew almost all the time stably from the direction of the ponds. According to the HYSPLIT (Draxler and Rolph, 2012) back trajectories, the air was arriving at the station following the coastline, about 100-200 km inland, over the margin of sheet and shelf ice as well as over the mountain ranges Gjelsvikfjella and Mühlig-Hofmannfjella.

The local NPF events (I-IV) started directly from the cluster mode, which is a clear indication that the new particle formation took place close by. Three of these events were apple type (I, III and IV) and one bump type (II). During event IV the wind direction was slightly varying, causing discontinuities in the size distribution (Fig. 3).

Due to the shape of the number size distribution during local events, the growth rate (GR) of newly formed particles could not be calculated. The formation rates of $1.6 \mathrm{~nm}$-sized negative clusters varied from 0.02 to $4.2 \mathrm{~cm}^{-3} \mathrm{~s}^{-1}$, the highest value being obtained during event III. 


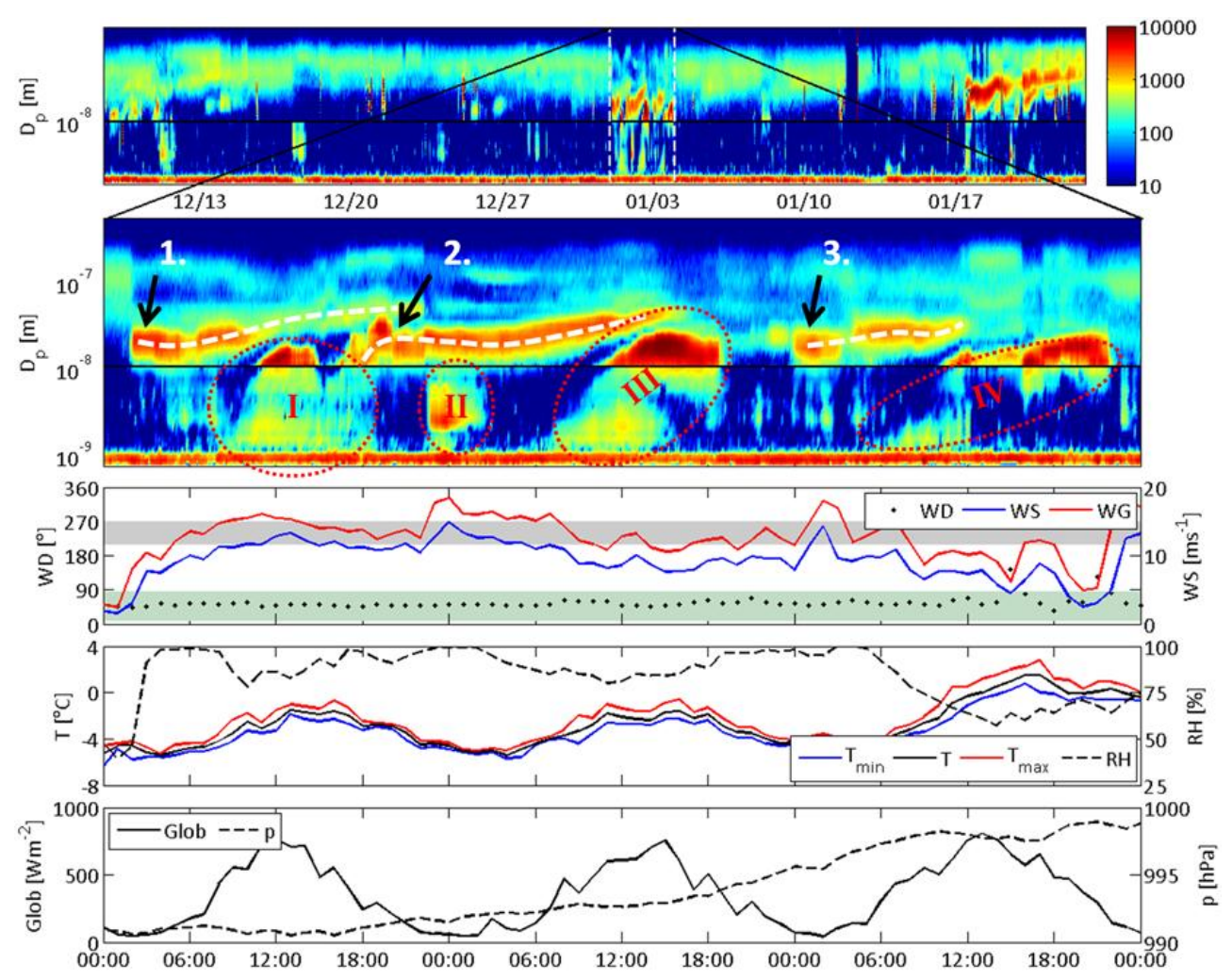

Fig. 3. Particle size distributions from AIS (negative polarity) and DMPS during the entire campaign (upper panel) and zoomed to the event period from 1 to 3 January 2010 (second panel). The colour scale is $\mathrm{dN} / \mathrm{d} \log D_{\mathrm{p}}$, unit $\mathrm{cm}^{-3}$. Local (I-IV) and regional NPF events (1-3) are also marked in the figure. The white dashed lines follow the growth of the regionally formed particles. Meteorological parameters (wind direction, speed and gust; average, minimum and maximum temperature as well as relative humidity; global radiation and pressure) during the event period are shown in the three lowermost panels. The shaded green and grey areas in the third panel show the pond $\left(10-85^{\circ}\right)$ and contamination $\left(210-270^{\circ}\right)$ sectors, respectively.

At the same time with the local events, also regional events (1-3) were observed. These events started from particles larger than $10 \mathrm{~nm}$, and the formed particles were seen to grow over several hours. The growth rates for the regional events varied between 0.9 and $5.6 \mathrm{~nm} \mathrm{~h}^{-1}$ and the formation rates of $10 \mathrm{~nm}$ particles $\left(J_{10}\right)$ varied from 0.08 to $0.3 \mathrm{~cm}^{-3} \mathrm{~s}^{-1}$ (Table 1).

\subsubsection{Event period 17 to 20 January 2010}

During the event period 17 to 20 January 2010, three local and two regional events were observed (Fig. 4). Two of the local events were apple-type (I and III) and one bump-type (II). In these events $J_{1.6-}$ varied from $8 \times 10^{-3}$ to $0.33 \mathrm{~cm}^{-3} \mathrm{~s}^{-1}$, the highest value being during event II. The GR and $J_{10}$ for the regional events varied from 1.8 to $8.8 \mathrm{~nm} \mathrm{~h}^{-1}$ and $3 \times 10^{-3}$ to $0.3 \mathrm{~cm}^{-3} \mathrm{~s}^{-1}$, respectively (Table 1).

The period started with a simultaneous observation of local and regional events. During this time, the wind speed was fairly low and the air mass was also rather stagnant (Fig. 5). The measured air mass was staying over the land, close to
Basen $24 \mathrm{~h}$ before arriving at the station. Even if the trajectory seemed to come from the direction of the ocean, the sea ice edge on January 2010 was some hundreds of kilometres from the shelf ice edge according to the National Snow and Ice Data Center. A few hours later, a cloud covered the station, and the cloud overpass continued from the evening of 17 January until noon 18 January.

During the local event II, air masses arriving at the station were coming from mountain range Vestfjella, to which Basen also belongs (Fig. 5). According to the wind direction observed at Aboa, the air masses passed the near-by mountain Plogen, where meltwater was also observed during the campaign. The local wind speed at Aboa increased to approximately $15 \mathrm{~m} \mathrm{~s}^{-1}$. At the end of the period, the air masses were stagnant again, staying over the surrounding area (Fig. 5). The intensity of the particle formation during local event III was quite weak, yet measurable.

\subsubsection{Wind-induced events}

In addition to the event periods, we observed five days during which we saw NPF events that did not grow above the 
Table 1. Obtained and calculated parameters for selected NPF events during 1 to 3 and 17 to 20 January 2010 . $T_{\text {med }}$ is the median temperature over the event time, WS is the wind speed at the onset of visible nucleation, $J_{1.6-}$ is the formation rate of 1.6-nm sized negative clusters and $J_{\text {assum }}$ is the nucleation rate assuming that the ion-induced nucleation explains $10 \%$ of the observed. $K$, which is the coefficient in Eq. (1), is assumed to be $10^{-12} \mathrm{~cm}^{-3} \mathrm{~s}^{-1} \cdot\left[\mathrm{H}_{2} \mathrm{SO}_{4}\right]_{\text {calc }}$ is the calculated atmospheric sulphuric acid concentration whereas $\left[\mathrm{H}_{2} \mathrm{SO}_{4}\right]_{\text {needed }}$ is the sulphuric acid concentration needed to explain the growth without organics. $\mathrm{GR}_{\text {calc }}$ is the GR that would result from the atmospheric sulphuric acid concentration and GR is the growth rate obtained from DMPS size spectrum using the "mode-fitting method" described in Dal Maso et al. (2005); Yli-Juuti et al. (2011). Also, the percentage that sulphuric acid explains of the growth is given. Event numbers refer to the ones marked in Figs. 3 and 4.

\begin{tabular}{|c|c|c|c|c|c|c|c|c|}
\hline Time & $\begin{array}{l}T_{\mathrm{med}} \\
{[\mathrm{K}] / \mathrm{WS}\left[\mathrm{m} \mathrm{s}^{-1}\right]}\end{array}$ & $\begin{array}{l}J_{1.6-} \\
{\left[\mathrm{cm}^{-3} \mathrm{~s}^{-1}\right]}\end{array}$ & $\begin{array}{l}J_{\text {assum }} / J_{10} \\
{\left[\mathrm{~cm}^{-3} \mathrm{~s}^{-1}\right]}\end{array}$ & $\begin{array}{r}{ }_{\left.\mathrm{H}_{2} \mathrm{SO}_{4}\right]_{\text {calc }}} \\
{\left[\text { molec. } \mathrm{cm}^{-3}\right]}\end{array}$ & $\begin{array}{l}\mathrm{GR}\left[\mathrm{nm} \mathrm{h}^{-1}\right] \\
\text { (size range) }\end{array}$ & {$\left[\mathrm{H}_{2} \mathrm{SO}_{4}\right]_{\text {needed }}$} & $\begin{array}{l}\mathrm{GR}_{\text {calc }} \\
{\left[\mathrm{nm} \mathrm{h}^{-1}\right]}\end{array}$ & Explained \% \\
\hline 1.1.2010 Event 1 & $270.4 / 11.3$ & 0.09 & $0.9 / 0.3$ & $9.5 \times 10^{5}$ & $5.5 \pm 0.2(24.1-45.9 \mathrm{~nm})$ & $1.05 \times 10^{8}$ & 0.050 & 0.9 \\
\hline 2.1.2010 Event 2 & $270.8 / 11.5$ & 0.1 & $1.0 / 0.2$ & $1 \times 10^{6}$ & $2.1 \pm 0.05(28.4-47.0 \mathrm{~nm})$ & $4.0 \times 10^{7}$ & 0.052 & 2.5 \\
\hline 3.1.2010 Event 3 & $272.3 / 9.7$ & 0.02 & $0.2 / 0.08-0.1^{*}$ & $4.5 \times 10^{5}$ & $5.6 \pm 0.11(26.9-90.2 \mathrm{~nm})$ & $1.1 \times 10^{8}$ & 0.023 & 4.2 \\
\hline 17.1.2010 Event 1 & $271.8 / 2.8$ & 0.27 & $2.7 / 0.3$ & $1.6 \times 10^{6}$ & $8.8 \pm 0.2(21.9-61.7 \mathrm{~nm})$ & $1.7 \times 10^{8}$ & 0.08 & 0.9 \\
\hline 20.1.2010 Event 2 & $268.6 / 5.2$ & 0.008 & $0.03 / 0.003$ & $1.7 \times 10^{5}$ & $1.8 \pm 0.3(34.8-67.8 \mathrm{~nm})$ & $3.5 \times 10^{7}$ & 0.01 & 0.5 \\
\hline
\end{tabular}

* Two bursts, 10:00-12:00 and 16:00-19:00 UTC, were observed in DMPS

detection limit of DMPS, but were visible in AIS (Fig. 6). All the events were observed during higher-than-average wind speeds. The median wind speed for the whole measurement campaign was $4.6 \mathrm{~m} \mathrm{~s}^{-1}$, whereas during wind-induced events on 11, 17, 23-24 and 28 December it was $12.1 \mathrm{~m} \mathrm{~s}^{-1}$, $8.1 \mathrm{~m} \mathrm{~s}^{-1}, 9.3 \mathrm{~m} \mathrm{~s}^{-1}$ and $8.4 \mathrm{~m} \mathrm{~s}^{-1}$, respectively. The events did not start directly from the cluster mode, as was the case for the events that were linked with meltwater production, but the formed ions were at the intermediate size. It has been previously seen at Aboa that high winds lead to the formation of $<10 \mathrm{~nm}$ intermediate size ions (Virkkula et al., 2007).

\subsection{Origin of the formed particles}

We hypothesize that the local particle production observed during the event periods was linked with emissions from the near-by Nostoc commune (Vaucher)-filled meltwater ponds, and that the regional particle formation was, to a large extent, associated with emissions from blue-ice areas as well as mountainous areas in Dronning Maud Land. We next search for evidence for this hypothesis and explore potential alternative explanations.

The colonial cyanobacterium Nostoc commune (Vaucher) is a cosmopolitan generalist, which exists in freshwater (Vincent and Howard-Williams, 1986, 1989; Moorhead et al., 1997) and terrestrial (Novis et al., 2007) environments and is widely spread around Antarctica from the surrounding islands (Broady, 1989) and Antarctic Peninsula to mountains (Broady, 1996), ponds (Holm-Hansen, 1964; Wharton Jr. et al., 1983) and dry valleys (Novis et al., 2007) in coastal and continental sites. It is also widely spread in the High Arctic (Sheath et al., 1996; Liengen and Olsen, 1997). It can survive extreme conditions, such as drought, freezing and UVradiation (Dodds et al., 1995). Migrating birds, such as Arctic tern (Sterna paradisaea), have been shown to disperse Nostoc commune in their tail feathers to Antarctica (Schlicting et al., 1978).
Nostoc commune (Vaucher) forms macroscopic colonies both on top of lake sediments and on soils. Recent findings suggest that the two forms, aquatic and terrestrial ones, have separated both genetically and ecologically (Novis and Smissen, 2006), and their responses to environmental factors differ from each other. Studies on terrestrial communities show a positive response to increasing temperature until $24^{\circ} \mathrm{C}$, after which respiration is expected to exceed net carbon fixation (Novis et al., 2007). In contrast, Vincent and HowardWilliams (1989) have shown a decrease in net carbon fixation at much lower temperatures (increase in temperature from 0 to $10^{\circ} \mathrm{C}$ ) for aquatic mats. Decomposition studies on aquatic Nostoc commune suggest that the thick mats of Nostoc can only exist due to cold temperatures that greatly depress the growth rates of bacterial decomposers (Vincent and HowardWilliams, 1989). In melt ponds the microbial mats are exposed to larger temperature changes than those that are living in the lakes (since they are living in the bottom of the lake). Therefore we can assume that the $N$. commune populations in meltwater ponds are closer to the terrestrial ones, which have much higher temperature optimum for net carbon fixation.

At Aboa, Nostoc commune is found mainly from the snowand ice-melting zones on the top of Basen (Sohlenius et al., 2004), but also terrestrial communities have been found. During the FINNARP 2009 expedition, the ponds were formed around Christmas and the cyanobacteria were exposed to sunlight around the New Year (Fig. 7). In addition, the occurrence of microfauna in Basen is much more frequent in Nostoc than in inorganic material (Sohlenius et al., 2004), and a number of different lichens species are also found from the mountain (Johansson and Thor, 2008).

\subsubsection{Evidence from air mass trajectories}

When investigating the origin of particles associated with the observed regional NPF events, we made two assumptions: 


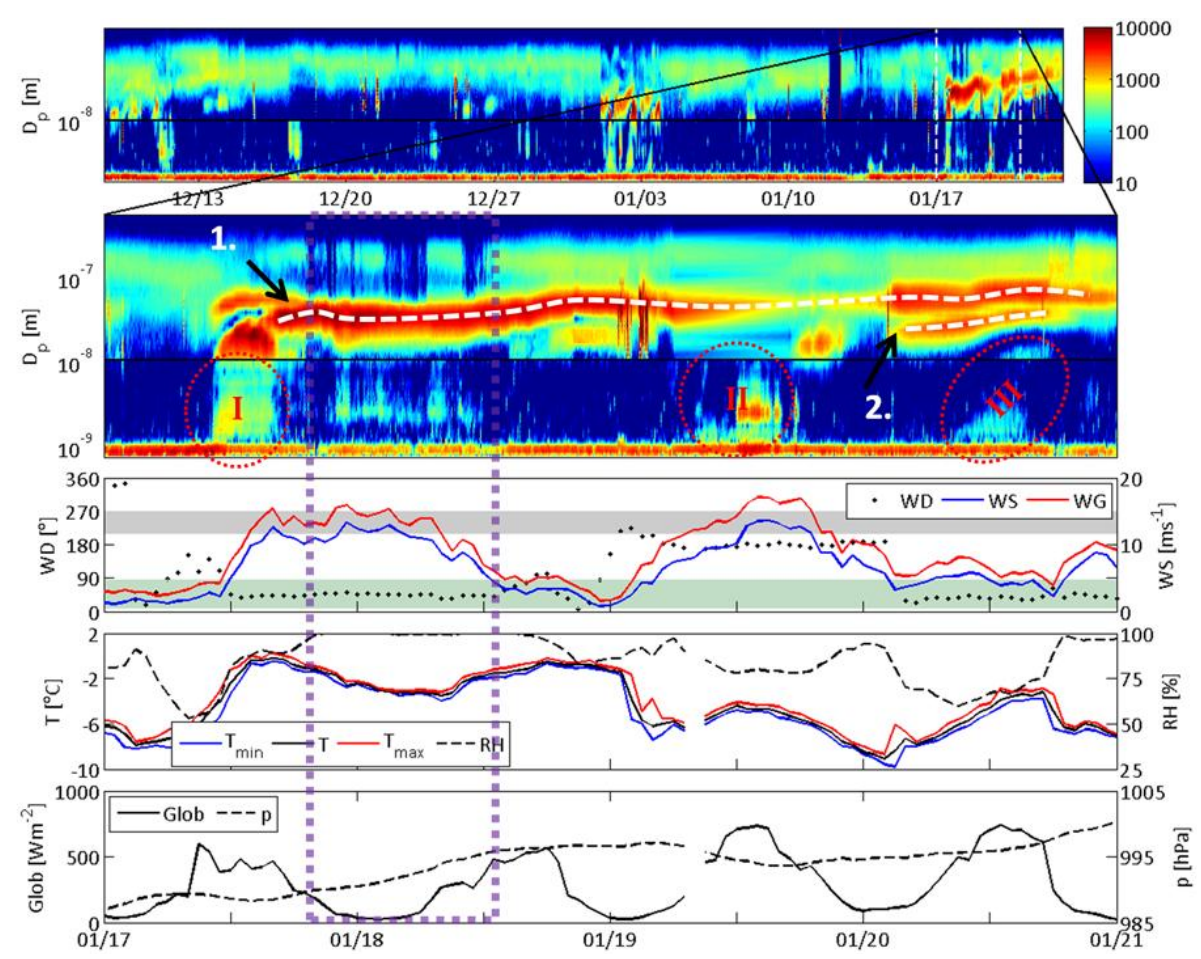

Fig. 4. Same as Fig. 3, except zoomed for the event period 17 to 20 January 2010. The period inside the cloud is marked with a dashed purple rectangle.

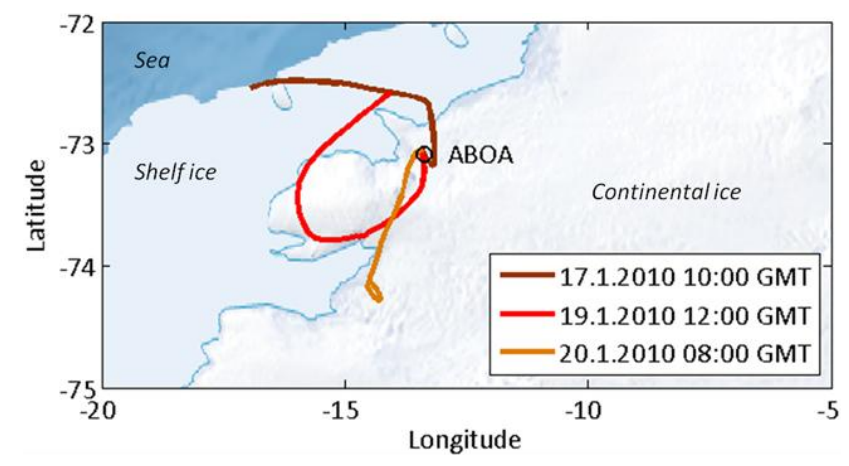

Fig. 5. The $24 \mathrm{~h}$ HYSPLIT back trajectories during the observed local events from 17 to 20 January 2010. Each time the air mass had been staying over the land and in the surrounding area over the last $24 \mathrm{~h}$. Continental and shelf ice are seen separately in the map. According to the National Snow and Ice Data Center, the sea ice edge next to Aboa was more than a hundred kilometres from the shelf ice edge in January 2010.

(1) particles grew initially very fast to sizes between about 5 and $15 \mathrm{~nm}$, as observed in our local NPF events, (2) particles then grew at about a constant rate until reaching our measurement site (the GR measured at Aboa). With these assumptions, and following the HYSPLIT back trajectories back in time, we could then determine the geographical area where the particles had roughly been formed, or where the precursors initiating NPF originated from.
According to our calculations, newly formed particles or their precursors originated mostly from the margin between the shelf ice and continental ice (Fig. 8). In this region, there is a large area of blue/superimposed ice (blue areas shown in Fig. 8 b and c). These blue-ice areas encase supraglacial lakes (Brandt and Warren, 1993), which experience surface melting during the summer (Liston and Winther, 2005), forming shallow ponds. A similar lake is also found near Aboa (Lehtinen and Luttinen, 2005). Some newly formed particles seemed to originate also from the mountain ranges Gjelsvikfjella, Mühlig-Hofmannfjella, Heimefrontfjella and Vestfjella.

\subsubsection{Evidence from chemical analyses}

When comparing NRF of organics and nucleation mode particle concentration, a clear correlation between the two was found (Fig. 9). We observed a clear correlation between the neutral (panel a) as well as charged (panels b-c) nucleation mode particle concentrations and the NRF of organics found from the filter samples. The correlation was greatest $\left(R^{2}=0.73\right)$ for the large negatively charged ions and smallest $\left(R^{2}=0.37\right)$ for the intermediate negatively charged ions.

Comparison of the chemical composition of studied aerosol samples and samples from the cyanobacteria and water revealed that some compounds having a high NRF during the NPF event days were also present in the algal and/or water samples (Table 2). From these compounds, three were 

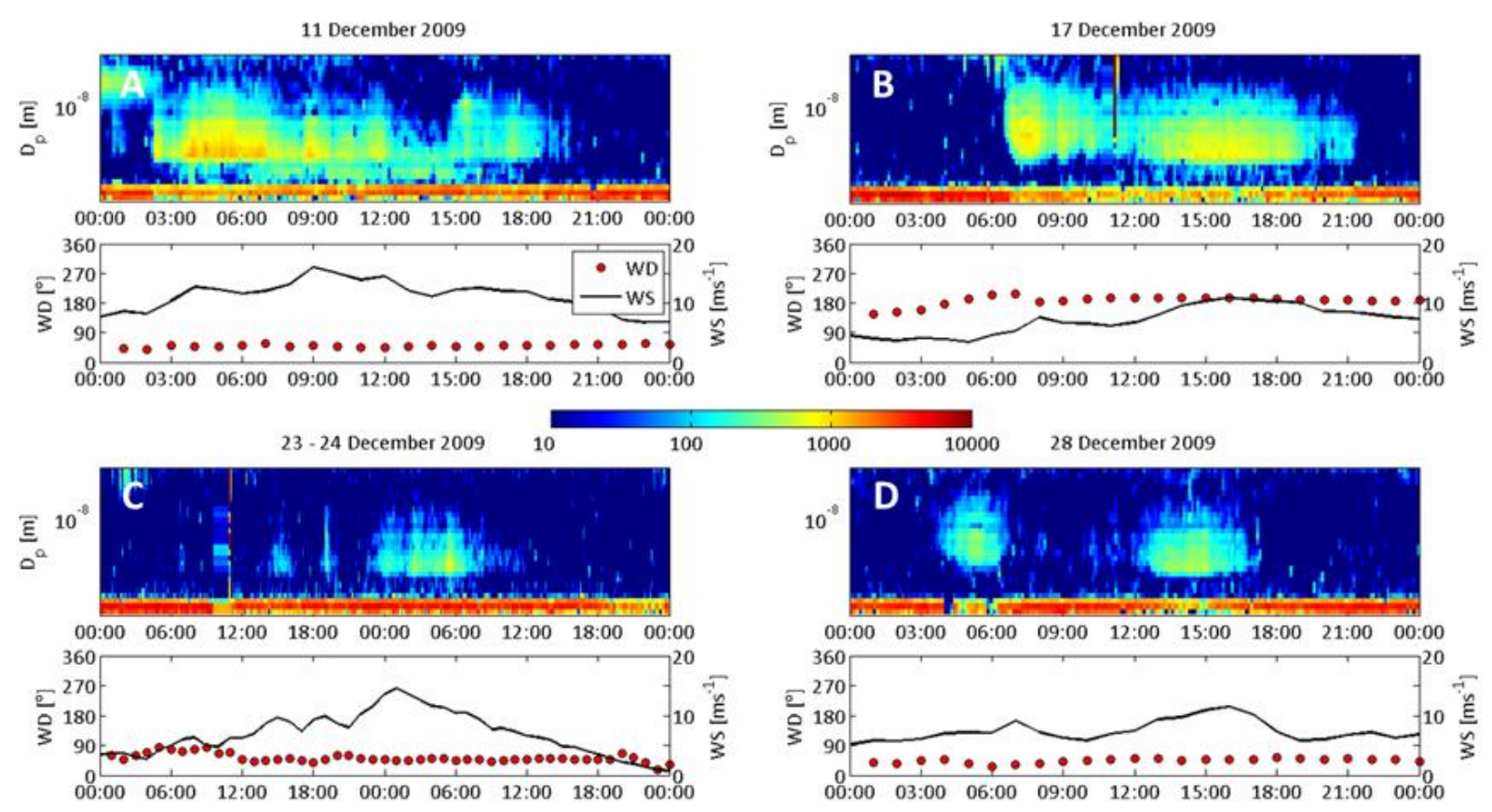

Fig. 6. Wind-induced events during December 2009. Boxes (A-D) show the particle size distribution from AIS (negative polarity) as well as wind direction and speed during five days of wind-induced events on December 2009. The colour scale in AIS surface plots is dN/dlog $D_{\mathrm{p}}$.

exclusively present in the aerosol particles collected during the event period 1 to 3 January 2010 and three were present in all the aerosol samples, with the highest NRF values (related to concentrations) in the samples collected during the event periods.

The first group of compounds, related to the pond melting, was also detected in water and the algae samples. Due to the lack of authentic standards, it was not possible to quantify these compounds in the samples. Although the NRF allowed the comparison of the results achieved between the different samples, it did not provide information about the real concentration of the compounds. The exclusive presence of some compounds and the increased NRF for some individual compounds in the particles collected during the event periods supported the role of NPF. In order to clarify this point, the NRF, expressed as percentage of $\sum N R F$, was calculated for these compounds (Table 3 ). The values for NRFs ranged between 0.5 and $2.4 \%$ in the case of the compounds present in the filter during the second event period ( 1 to 3 January 2010). In the case of the compounds present in all aerosol samples, the NRF values ranged between 1.4 and $5.5 \%$ in the period from 1 to 3 January 2010 and between 0.8 and $3.1 \%$ in the period from 17 to 20 January 2010 . These values are surprisingly high in comparison with the average NRF for these compounds in the particles collected during non-event days $(0.18 \%)$.

Although the theoretical vapour pressures of the compounds present in the groups 1 and 2 are not high enough (Table 4) to allow them to evaporate from the ponds more
Table 2. Organic compounds found from filter as well as water and algal samples. Group 1 compounds were present in the filter samples during the second event period, whereas Group 2 compounds were present during all event periods, but their absolute concentration and contribution to the total organics was greatest during the second period. Compounds labelled with "A" have been found from algal and "W" from water samples.

\begin{tabular}{llll}
\hline Group 1 & & Group 2 & \\
\hline 1-Hydroxy-3-oxopropane- & A & 1,4-Bis(sulfanyl)butane- & A \\
1,2,3-Tricarboxylic acid & & 2,3-diol & \\
1-Iodo-2-methylundecane & A,W & Hexanedioic acid & A \\
1-Iodo-2-methylnonane & A,W & 2,2-Dimethylhexan-1-ol & A \\
\hline
\end{tabular}

than what is their saturation concentration, it is possible that primary particles emitted by the ponds contained these compounds. In addition, some potential precursors of these compounds were found in the water and aerosol samples (Table 5). Thus, the compounds in pond samples were oxidised from these precursors while being in the ponds, whereas the same compounds found from the filter samples were oxidised in the atmosphere from the precursors and transferred to the particles either by nucleation or condensation. 


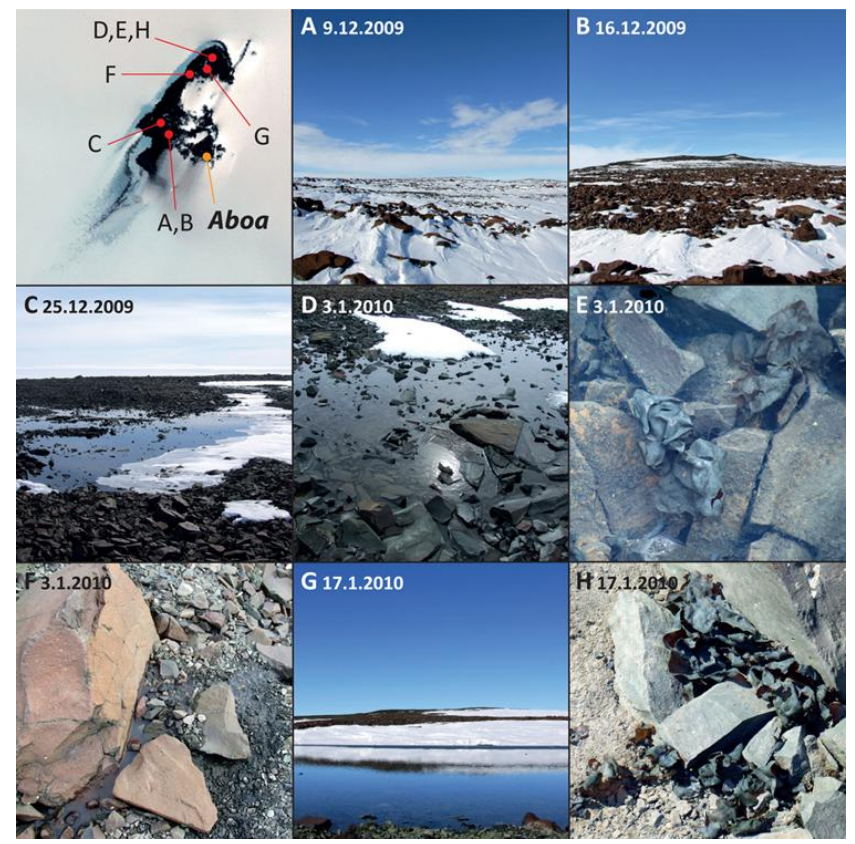

Fig. 7. Formation of the ponds and exposure of the cyanobacteria. The map in the upper left corner shows the locations where the photos were taken. On 9 December 2010 the top of Basen was still under snow (A) and on 16 December there was clearly less snow (B), but open ponds were not formed. The first ponds were observed on 25 December $(\mathbf{C})$ and the samples from water and microbial mats of Nostoc commune (Vaucher) were taken on 3 January 2010 (DE). On that day, also underground trickles (F) were observed. A big lake, approximately $100 \mathrm{~m}^{2}$ in area, formed in the first half of January (G) and even more Nostoc commune (Vaucher) was found on 17 January $\mathbf{( H )}$. The satellite image is downloaded from Landsat Image Mosaic of Antarctica (LIMA), http://lima.usgs.gov/. The mentioned days are the only days when the top of the mountain was visited and photographed.

\subsubsection{Other possibilities}

In order to be sure that the observed local NPF and subsequent growth was caused by the near-by meltwater ponds, we investigated other possible factors that could cause changes in particle size spectrum similar to the events observed here. These include the intrusion of air (and dimethyl sulphide, DMS) from higher altitudes, the possibility that the air mass had stayed over open ocean and picked up aerosol precursors from there, contamination, and changes in the condensation and coagulation sinks.

The influence of air intrusion from higher altitudes was ruled out by using the ozone concentration as an indicator. Since there are no local sources for $\mathrm{O}_{3}$, this can be done with a good accuracy. Figure 10 shows the ozone and nucleation mode concentration over the entire campaign. The NPF periods are shown with shaded light yellow, light blue and pink areas and the median ozone concentration during those periods is given. The median ozone concentration over the whole
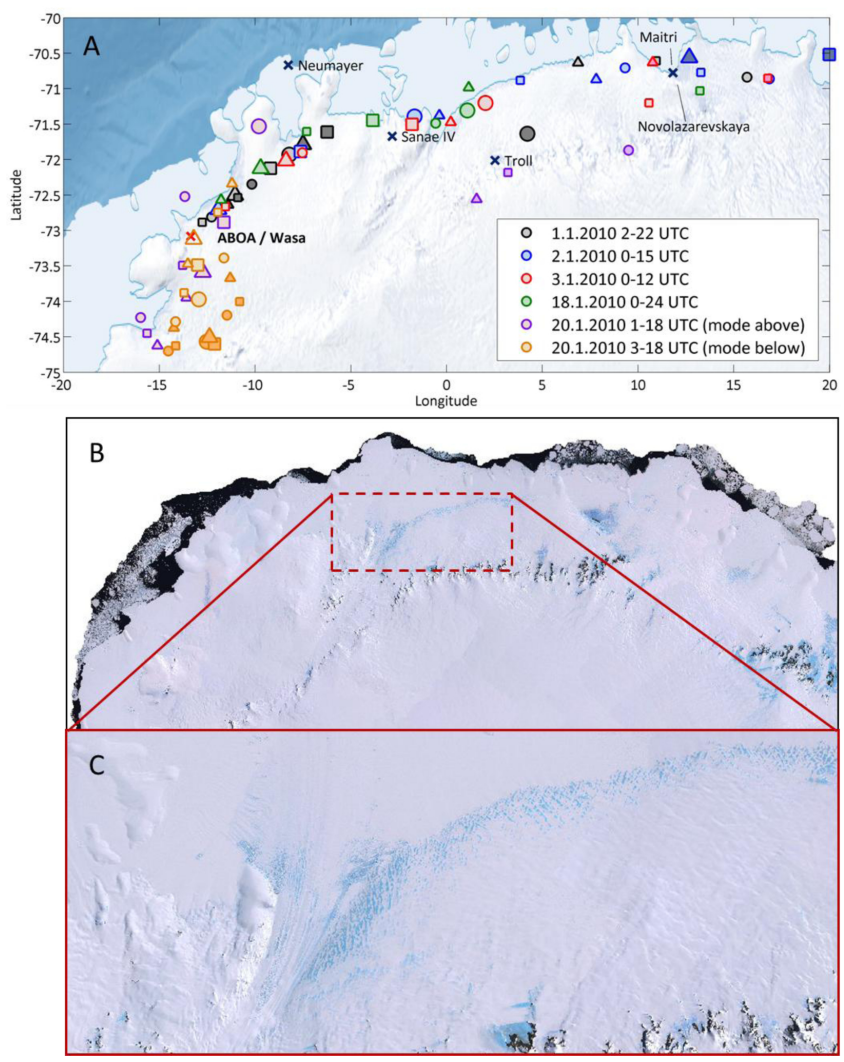

Fig. 8. Origin of Aitken mode particles associated with the observed regional nucleation events. Panel (A) shows the estimated source areas of Aitken mode particles calculated along back trajectories by assuming that the particles grew in size during their atmospheric transportation at the same rate as observed in our measurement site. The "initial diameter" of these particles was assumed to be $5 \mathrm{~nm}$ (circle), $10 \mathrm{~nm}$ (square) or $15 \mathrm{~nm}$ (triangle), which represents the uncertainties in the very fast growth of nucleated particles in the immediate vicinity of their emission source as seen during the local events in Figs. 3 and 4. The different colours of the markers (see the legend) refer to different nucleation events or, in case of 20 January, to two separate Aitken modes observed during the same event. For each event, we visually selected 6 spots in the particle size vs. time space that we followed using trajectories: the lower (light-coloured marker) and upper (dark-coloured marker) end of the Aitken mode in the middle (large marker) of the event or at the beginning or end (small marker) of the event. Panels (B) and (C) show LANDSATsatellite images over the same area showing larger areas of meltwater in the border between the shelf ice and ice sheet. Satellite images are downloaded from the LIMA web page, http://lima.usgs.gov/.

campaign is also shown. From the figure it is clear that only the first event period (9 to 11 December 2009) occurred when the $\mathrm{O}_{3}$ concentration was higher than average, whereas the two periods where we observed local NPF took place when the $\mathrm{O}_{3}$ concentration was lower than average.

According to the HYSPLIT back trajectories, each time when a local NPF event was observed at Aboa, the air mass had not descended from higher altitudes but rather arrived 

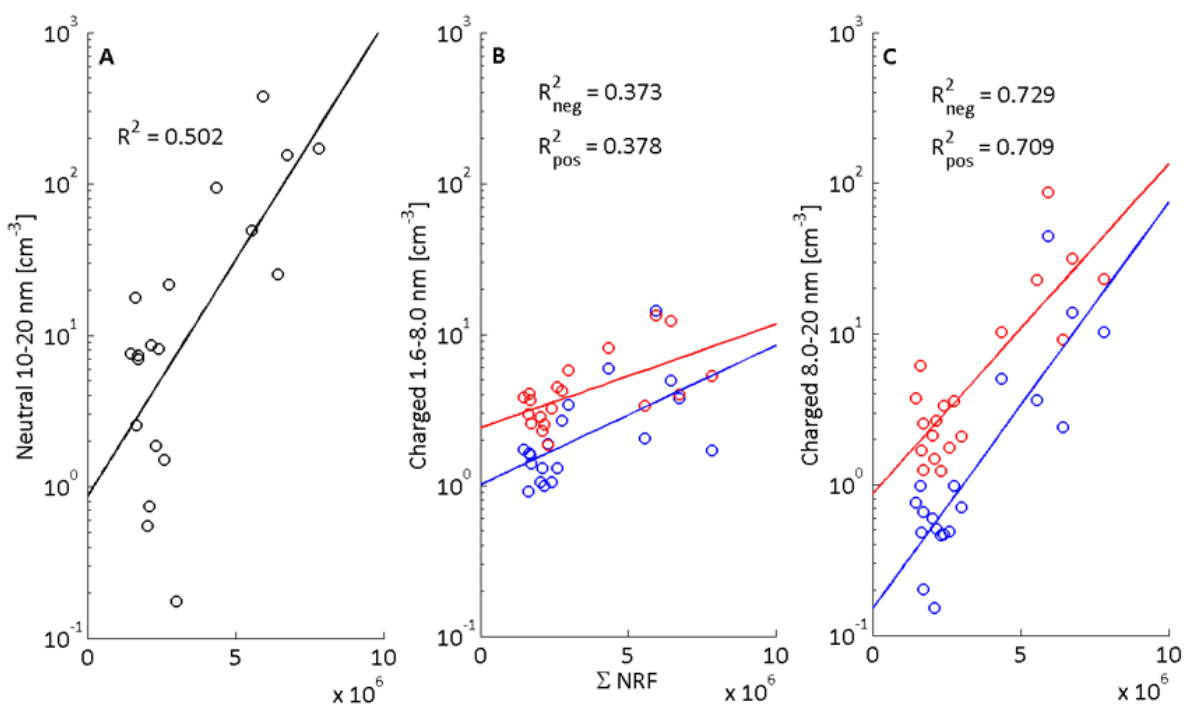

Fig. 9. The correlation between NRF and neutral 10-20 nm (A), charged 1.6-8.0 nm (B) and charged 8.0-20 nm (C) particles. The particle concentrations are medians over filter sampling times (2-3 days). The red and blue curves and points represent the positive and negative ions, respectively.

Table 3. Percentage of $\sum N R F$ calculated for group 1 and 2 compounds.

\begin{tabular}{lcc}
\hline Sample & \multicolumn{2}{c}{$\%$ of $\sum$ NRF } \\
& Group 1 & Group 2 \\
\hline $08.12-10.12$ & 0.0 & 2.2 \\
$10.12-12.12$ & 0.0 & 1.5 \\
$12.12-15.12$ & 0.0 & 0.2 \\
$15.12-17.12$ & 0.0 & 0.1 \\
$17.12-19.12$ & 0.0 & 0.4 \\
$19.12-22.12$ & 0.0 & 0.2 \\
$22.12-24.12$ & 0.0 & 0.2 \\
$24.12-26.12$ & 0.0 & 0.1 \\
$26.12-29.12$ & 0.0 & 0.1 \\
$29.12-31.12$ & 0.0 & 0.1 \\
$31.12-2.1$ & 6.5 & 10.5 \\
$02.01-05.01$ & 5.8 & 6.8 \\
$05.01-07.01$ & 0.0 & 0.2 \\
$07.01-09.01$ & 0.0 & 0.3 \\
$09.01-12.01$ & 0.0 & 0.2 \\
$12.01-14.01$ & 0.0 & 0.1 \\
$14.1-16.1$ & 0.0 & 0.2 \\
$16.1-19.1$ & 0.0 & 2.7 \\
$19.1-21.1$ & 0.0 & 6.9 \\
\hline
\end{tabular}

from close to the ground level (Fig. 11). The trajectories were calculated to arrive at $500 \mathrm{~m}$ above the ground level (a.g.l.). With this arrival height in the HYSPLIT model, the real arrival height to the measurement site was approximately $250 \mathrm{~m}$, since nunatak Basen is not included to the HYSPLIT terrain. Aboa is located on a plateau $250 \mathrm{~m}$ above the glacier.
HYSPLIT back trajectories were also used in order to exclude the trajectories that had been over the ocean. The trajectories were calculated at $500 \mathrm{~m}$ a.g.1., $48 \mathrm{~h}$ backwards from each local NPF event. Approximately half of these trajectories were not over the sea at any point and none of the trajectories were over sea less than $24 \mathrm{~h}$ before arriving at the station. Matrix trajectories (trajectories that are arriving at slightly different coordinates) as well as trajectories at different heights were also calculated in order to validate the sensitivity of the trajectories, and these calculations showed similar behaviour of the air mass.

According to the National Snow and Ice Data Center, the January 2010 sea ice conditions at the coastline of Dronning Maud Land (DML) were close to the median values. The sea ice on the western side of DML was extending more than a hundred kilometres from the coast, almost all of the Weddell Sea was covered with ice, and the sea ice on the eastern side of DML was also extending some tens of kilometres from the coastline, with only a narrow band of ice-free coast at the central part of DML. Even if some of the trajectories seemed to have been over the ocean at some point (all more than 24 hours before arrival) in their path, they were still over the sea ice and not over open ocean. Thus, the observed local events cannot be explained by emissions from the sea.

The contamination sector at Aboa is well defined, 210$270^{\circ}$, all the infrastructure and vehicle tracks being in that direction. Also the Swedish station Wasa, only $200 \mathrm{~m}$ from Aboa, is in that direction. During the campaign, the wind blew only $4.6 \%$ of the time from the contamination sector.

Contamination of the regional observation can be ruled out simply by considering the scale of the regional particle formation events. For the local emissions, we studied 
Table 4. Theoretical vapour pressure $\left(P_{0}\right)$ and vaporization enthalpy $\left(\Delta H_{\mathrm{vap}}\right)$ for the compounds contained in groups 1 and 2.

\begin{tabular}{lcc}
\hline Compounds & $P_{0}\left(\mathrm{mmHg}\right.$ at $\left.25^{\circ} \mathrm{C}\right)$ & $\Delta H_{\mathrm{vap}}\left(\mathrm{KJ} \mathrm{mol}^{-1}\right)$ \\
\hline 1-Hydroxy-3-oxopropane-1,2,3-tricarboxylic acid & $4.01 \times 10^{-10}$ & 80.4 \\
1-Iodo-2-methylundecane & $2.0 \times 10^{-3}$ & 51.5 \\
1-Iodo-2-methylnonane & $2.2 \times 10^{-2}$ & 47.6 \\
1,4-Bis(sulfanyl)butane-2,3-diol & $5.17 \times 10^{-5}$ & 70.6 \\
Hexanedioic acid & $1.28 \times 10^{-5}$ & 63.9 \\
2,2-Dimethylhexan-1-ol & $6.2 \times 10^{-1}$ & 48.8 \\
\hline
\end{tabular}

Table 5. Potential identified precursors in water and aerosol phases for the compounds in groups 1 and 2.

\begin{tabular}{ll}
\hline Compounds & Precursors \\
\hline 1-Hydroxy-3-oxopropane-1,2,3-tricarboxylic acid & Malic acid, oxalic acid, maleic acid \\
1-Iodo-2-methylundecane & Undecanol, undecene, undecene nitrile, sulphuric acid, sodium iodine \\
1-Iodo-2-methylnonane & Nonanol, nonanal, nonene, sulphuric acid, sodium iodine \\
1,4-Bis(sulfanyl)butane-2,3-diol & - \\
Hexanedioic acid & Cyclohenanone, butadiene, cyclohexanol, nitric acid \\
2,2-Dimethylhexan-1-ol & - \\
\hline
\end{tabular}

signatures of known contamination (such as snowmobiles) and found that the duration and shape of the observed appletype events was markedly different from the contamination signature. Contamination is observed in particle size spectrometers (DMPS, AIS) as short peaks in concentration in most size bins, appearing and disappearing quickly (Fig. 12). This is contrary to local NPF events that appear as continuous particle formation over several hours, without sharp gaps in between. Also, the particles that are seen during contamination are always larger than $10 \mathrm{~nm}$ in size. Thus, neither the contamination from Aboa nor from neighbouring stations (German Neumayer $350 \mathrm{~km}$ or South African SANAE IV $420 \mathrm{~km}$ away) can explain the observed local NPF events.

Changes in pre-existing aerosol as a cause to our observations can be ruled out by analysis of the time series of condensation and coagulation sinks at Aboa. The sinks were generally very low, due to the minimal aerosol loading over Antarctica, and NPF can therefore be considered to be limited by the aerosol source rather than the vapour and particle sink. Additionally, we did not observe a reduction of the computed sink values prior to the observations of NPF.

The time series of condensation and coagulation sinks (CS and CoagS, respectively) together with the time series of nucleation mode particle concentration are presented in Fig. 13. All three NPF event periods are marked in the figure with shaded areas. During the entire campaign, the median values for CS and CoagS were $4.0 \times 10^{-4}$ and $4.2 \times 10^{-6} \mathrm{~s}^{-1}$, respectively. While the CS and CoagS values over the first event period (9 to 11 December 2009) were only slightly higher than these median values, during the second event period (1 to 3 January 2010) CS and CoagS were lower than compared with the entire campaign. During the last period,
17 to 20 January 2010 , the values were an order of magnitude larger. Since local events occurred both in the second and third event period, high or low CS and CoagS did not affect the probability of local NPF. The value of CS correlated moderately with both Aitken and accumulation mode particle number concentrations (Fig. 14), as expected since these particles form the dominant $\mathrm{CS}$, but had no correlation with the nucleation mode particle concentration (Fig. 14).

\subsection{Particle growth and particle interaction with clouds}

We next investigate the growth of newly formed particles in order to find out (i) which vapours were responsible for their growth, and (ii) whether these particles grew sufficiently large to be able to interact with clouds as observed previously in the Arctic atmosphere (Kerminen et al., 2005; Komppula et al., 2005).

\subsubsection{Contribution of sulphuric acid to the particle growth}

The rate at which the newly formed aerosol population grows can be determined from the measured number size distributions by following the geometric mean size of the nucleation mode particles (Dal Maso et al., 2005; Yli-Juuti et al., 2011). During both local and regional NPF events observed here, the particle growth appeared to be very rapid compared with previous observations from Antarctica (Kulmala et al., 2004; Yu et al., 2008). We next investigate which fraction of the particle growth can be explained by sulphuric acid and to which extend other condensing vapours are needed.

Lacking direct sulphuric acid measurements, we estimated limiting values for the sulphuric acid concentrations by 

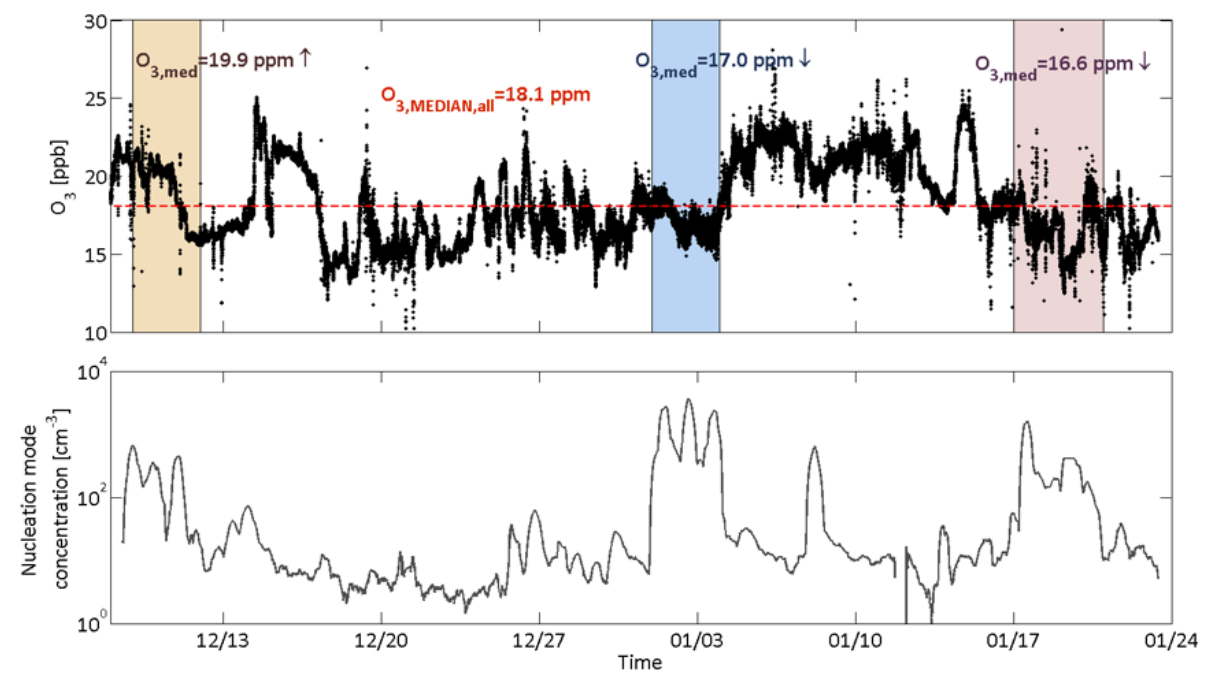

Fig. 10. Ozone concentration (A) and nucleation mode concentration (B) during the entire campaign. The event periods are shaded with light yellow (9 to 11 December 2009), light blue (1 to 3 January 2010) and pink (17 to 20 January 2010). The median ozone concentration during the campaign is marked with a red line.

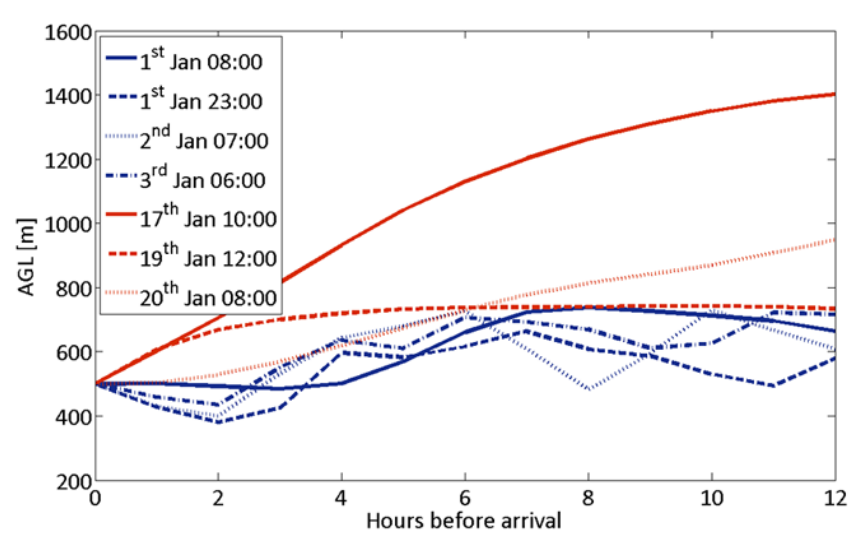

Fig. 11. Trajectory height above ground during event periods 1 to 3 and 17 to 20 January 2010.

assuming that the aerosol formation was driven by a kinetic sulphuric acid nucleation mechanism. The kinetic theory (McMurry and Friedlander, 1979) assumes that the rate limiting step in nucleation is the collision of two sulphuric acid molecules as in kinetic gas theory, and that a fraction of these collisions lead to the formation of stable clusters. This leads to a formulation that gives the nucleation rate a quadratic dependence of the sulphuric acid concentration:

$J=k\left[\mathrm{H}_{2} \mathrm{SO}_{4}\right]^{2}$.

Here $k$ is a coefficient that incorporates both the collision frequency and the stable cluster formation probability. It has been found that the value of $k$ averages about of $10^{-12} \mathrm{~cm}^{-3} \mathrm{~s}^{-1}$ in the atmosphere (Paasonen et al., 2010), so we used this value for our estimation (Table 1). In addition, the theoretical upper limit $\left(10^{-10} \mathrm{~cm}^{-3} \mathrm{~s}^{-1}\right)$ and the lowest reported value $\left(10^{-14} \mathrm{~cm}^{-3} \mathrm{~s}^{-1}\right)$ were used. The $\mathrm{H}_{2} \mathrm{SO}_{4}$ concentrations obtained this way are in a good agreement with a recent modelling study (Yu and Luo, 2010) that yielded concentrations in the range of $\sim 0.6-1.5 \times 10^{6}$ molecules $\mathrm{cm}^{-3}$ in the Antarctic coastal areas in the austral summer (DecemberFebruary), as well as with the directly measured values from South Pole (Mauldin et al., 2004, 2010) and Antarctic Peninsula (Jefferson et al., 1998a).

We obtained the observed values for the nucleation rate $J$ (Table 1) from the particle formation rates measured by the AIS according to the methodology described by Kulmala et al. (2007) and Manninen et al. (2010). From these, we could then estimate the upper and lower boundaries for the sulphuric acid concentration using Eq. (2). From the aerosol size distribution data, we obtained the modal growth rate of Aitken-mode (size of 20-100 nm) particles following the mode-fitting methodology described in Dal Maso et al. (2005) and Yli-Juuti et al. (2011). Since the particle diameter growth in this size range and at the observed concentrations range is to any observable extent mainly due to vapour condensation, we could compare the observed growth rate to the theoretical prediction of the growth rate in the case that only sulphuric acid was growing the particles. In this approach, the sulphuric acid concentration required for a given diameter growth is given by (McMurry and Friedlander, 1979; Nieminen et al., 2010)

$$
\begin{aligned}
C_{\mathrm{v}} & =\frac{2 \rho_{\mathrm{v}} d_{\mathrm{v}}}{\alpha_{\mathrm{m}} m_{\mathrm{v}} \Delta t} \cdot \sqrt{\frac{\pi m_{\mathrm{v}}}{8 k T}} \cdot\left[\frac{2 x_{1}+1}{x_{1}\left(x_{1}+1\right)}-\frac{2 x_{0}+1}{x_{0}\left(x_{0}+1\right)}\right. \\
& \left.+2 \ln \left(\frac{x_{1}\left(x_{0}+1\right)}{x_{0}\left(x_{1}+1\right)}\right)\right] .
\end{aligned}
$$

Here, $C_{\mathrm{v}}$ is the vapour concentration, $\rho_{\mathrm{v}}$ is the vapour density, $m_{\mathrm{v}}$ is the molecular mass of the vapour, $k$ is the 

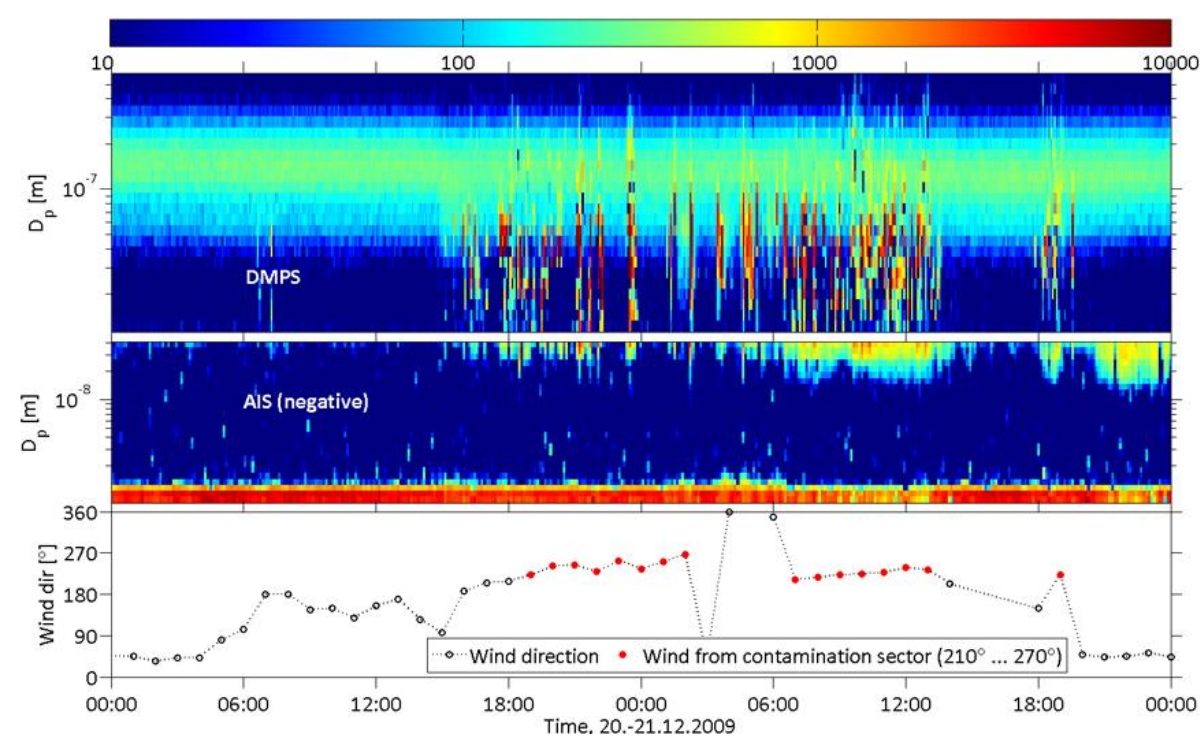

Fig. 12. Contamination at Aboa, 20-21 December 2009. Upper and middle panel show the neutral (10-500 nm, upper) and negatively charged (0.8-42 nm, middle) particle size distribution, while the lowermost panel shows the $1 \mathrm{~h}$ averaged wind direction. Wind direction values marked with red are coming from the contamination sector. The contamination sector at Aboa is well defined, and during the campaign wind blew from this sector only $4.6 \%$ of the time. The colour scale in size distributions is $\mathrm{dN} / \mathrm{d} \log D_{\mathrm{p}}$, unit $\mathrm{cm}^{-3}$.

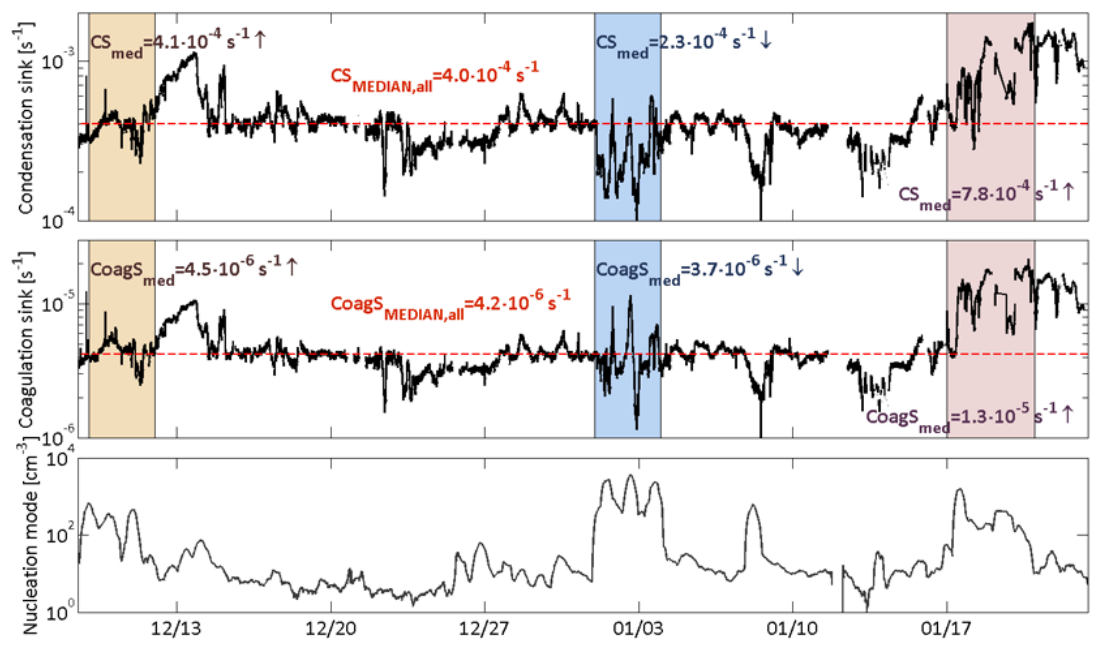

Fig. 13. Condensation and coagulation sinks and nucleation mode concentration during the measurement campaign. The uppermost and middle panel show the condensation and coagulation sink during the whole measurement campaign, respectively. The lower panel shows the nucleation mode concentration as calculated from DMPS for the same time period. The event periods are shaded with light yellow (9 to 11 December 2009), light blue (1 to 3 January 2010) and pink (17 to 20 January 2010). Median CS and CoagS values for the event periods and for the whole measurement campaign are shown as well. The coagulation sink was calculated for $11 \mathrm{~nm}$ sized particles.

Boltzmann constant, and $T$ is temperature. $x_{1}=d_{\mathrm{v}} / d_{\mathrm{p}}$ and $x_{0}=d_{\mathrm{v}} / d_{\mathrm{p} 0}$, where $d_{\mathrm{v}}$ is the vapour molecule diameter, $d_{\mathrm{p}}$ is the particle diameter at the end of growth, and $d_{\mathrm{p} 0}$ is the initial particle diameter. $\alpha_{\mathrm{m}}$ is the mass accommodation coefficient and $\Delta t$ is the elapsed time. Setting the diameter growth to $1 \mathrm{~nm} \mathrm{~h}^{-1}$ in the above equation, we get a vapour concentration multiplier $\gamma_{\mathrm{GR}=1}$ (in molecules $\mathrm{cm}^{-3} \mathrm{~nm}^{-1} \mathrm{~h}$ ) for the sulphuric acid growth rate, essentially corresponding to the $\mathrm{H}_{2} \mathrm{SO}_{4}$ concentration causing a growth rate of $1 \mathrm{~nm} \mathrm{~h}^{-1}$.
Knowing the sulphuric acid concentration, the growth rate caused by it is now given by (Paasonen et al., 2010)

$\mathrm{GR}_{\mathrm{H}_{2} \mathrm{SO}_{4}}=\frac{\left[\mathrm{H}_{2} \mathrm{SO}_{4}\right]}{\gamma_{\mathrm{GR}=1}}$.

In Table 1, we have compared the observed growth rates $\left(\mathrm{GR}_{\mathrm{obs}}\right)$ to the sulphuric acid growth rate when assuming the value of $k$ to be equal to $10^{-12} \mathrm{~cm}^{-3} \mathrm{~s}^{-1}$. By assuming $k$ to be two orders of magnitude lower $\left(k=10^{-14} \mathrm{~cm}^{-3} \mathrm{~s}^{-1}\right)$, 

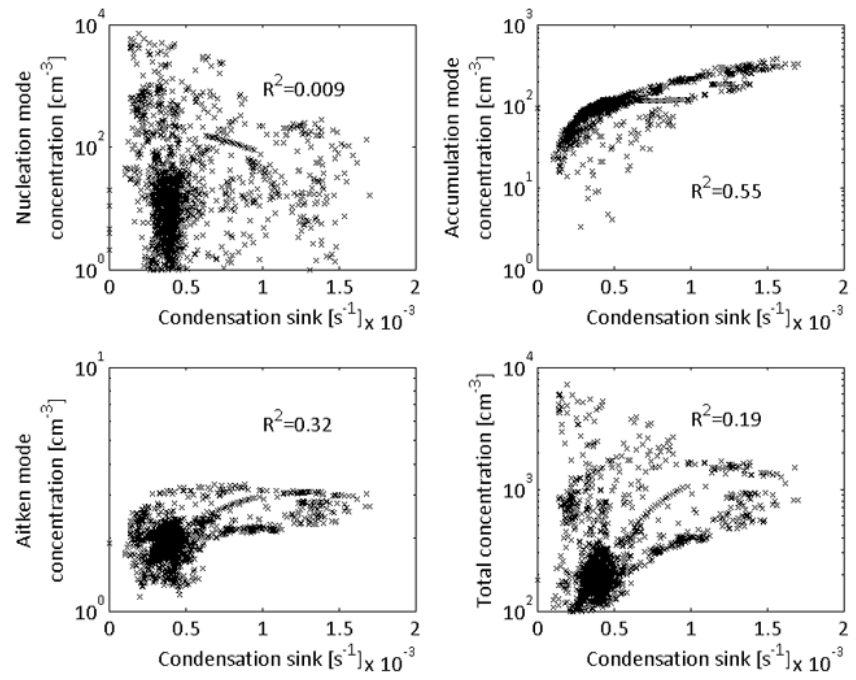

Fig. 14. Correlation of condensation sink with different particle mode concentrations.

the percentages given in Table 1 would be ten times higher and at maximum $42 \%$ of the observed particle growth rate would be explained by sulphuric acid condensation. By assuming the theoretical upper limit for $k\left(10^{-10} \mathrm{~cm}^{-3} \mathrm{~s}^{-1}\right)$, the corresponding percentages would be ten times lower.

We conclude that vapours other than sulphuric acid dominated the growth of newly formed particles in our observations. The most likely candidates for such vapours are highly oxidised, extremely low-volatile organic vapours (Pierce et al., 2011; Riipinen et al., 2011; Ehn et al., 2012). Some measurements of MSA (methane sulphonic acid) have been made in the Antarctic Peninsula, but the measured values are far from being sufficient enough to explain the observed growth (Jefferson et al., 1998b). The identity and formation pathways of these vapours, as well as their relation to meltwater ponds, remain to be quantified.

\subsubsection{Cloud droplet activation}

Particle number size distribution measurements can be used to investigate the size-dependent activation of aerosol particle into cloud droplets (Komppula et al., 2005; Lihavainen et al., 2008; Anttila et al., 2009). More specifically, such measurements make it possible to determine the activation diameter $\left(D_{50}\right)$, i.e. the "dry" particle diameter above which the probability for cloud droplet activation exceeds $50 \%$ in the cloud under consideration. A successful determination of the value of $D_{50}$ requires that the cloud is non-precipitating and that $D_{50}$ is above the size range in which coagulation of cloud interstitial aerosol particles with cloud droplets starts to influence the particle number size distribution. The latter phenomenon is unlikely to be important above $20-30 \mathrm{~nm}$ of particle dry diameter (Komppula et al., 2005; Lihavainen et al., 2007).
During our measurement campaign, a sequence of cloud droplet action events from 17 to 18 January showed that even fairly small particles were able to act as cloud condensation nuclei. The station was inside a cloud three times during these days: from 19:30 to 22:00 on 17 January, and from 03:00 to 07:00 and from 10:30 to 12:00 on 18 January (Fig. 15). We can see the smallest size bin where some activation occurred was $48 \mathrm{~nm}$. The median value of $D_{50}$, determined following Komppula et al. (2005), was $60 \mathrm{~nm}$ during the three cloud periods (Fig. 16). Such a small activity diameter can be explained by the low number concentrations of particles larger than $100 \mathrm{~nm}$ in diameter which, compared with more polluted air, allows the development of a higher cloud supersaturation (McFiggans et al., 2006).

\section{Summary and conclusions}

We observed two periods of local and regional particle formation at the Finnish Antarctic Research Station Aboa. The particle formation was intense, and to our knowledge, this was the first time that local non-polluted NPF events were observed in Antarctica. The amount of organics observed in filter samples and nucleation mode particle concentration showed a positive correlation over the campaign. By careful investigation, we could link the local particle formation to near-by meltwater ponds and cyanobacteria Nostoc commune (Vaucher) living abundantly in the ponds. Regional NPF events could be linked with blue-ice and mountainous areas, both known to have meltwater during the summer.

Evidence of the ponds being the source of the NPF precursor vapours was derived from analysis of the air mass transport before it reached the measurement station. For the local events, we investigated local wind direction measurements and found that during the local events, air masses came from the direction of recently formed meltwater ponds. This evidence was backed up by chemical analysis of aerosols during such time periods, which showed a markedly elevated signal of organic compounds. The same compounds were identified in the analysis of the pond water.

For regional events, evidence for the meltwater pond source was presented by air mass analysis using computed back trajectories for the observed regional events. The analysis showed that air had travelled over areas that are commonly covered by meltwater ponds during the time of the year that the events were observed.

Figure 17 summarizes our current understanding of the continental new particle formation in Antarctica. Meltwater ponds release organics that are, after oxidation in the atmosphere, capable of increasing the condensational growth of aerosols enough for them to have climatic effects via cloud condensation nuclei activation and probably increasing the nucleation as well. It has also been suggested (Antony et al., 2010) that the bromine emissions from coastal ice caps would increase the oxidation of DMS and could therefore increase the nucleation even in areas with no meltwater. 


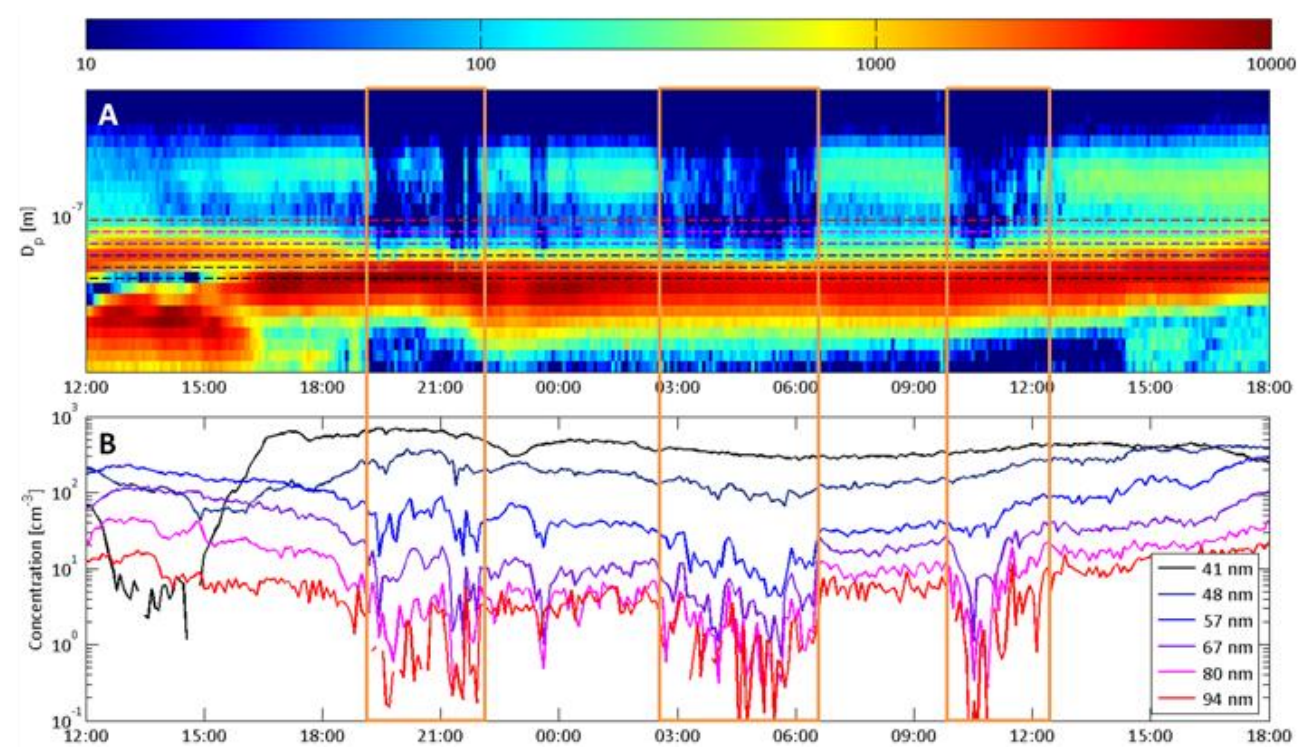

Fig. 15. Cloud droplet activation event during three cloud cover periods from 17 to 18 of January 2010. The times when the station was inside a cloud are denoted with orange boxes. The particle size distribution is shown in panel (A), whereas the total concentrations for 41, 48, 57, 67, 80 and $94 \mathrm{~nm}$ sized particles are shown in panel (B). Same size bins are shown with correspondingly coloured dashed lines in the surface plot. No activation is seen in the smallest size bin, $41 \mathrm{~nm}$, but already some particles are activated in the next, $48 \mathrm{~nm}$ size bin (see the first and second cloud cover period, where the small decreases in concentration of $48 \mathrm{~nm}$ particles happen at the same time as in the larger sizes), and finally the activation is very clear in the $57 \mathrm{~nm}$ sized particles.
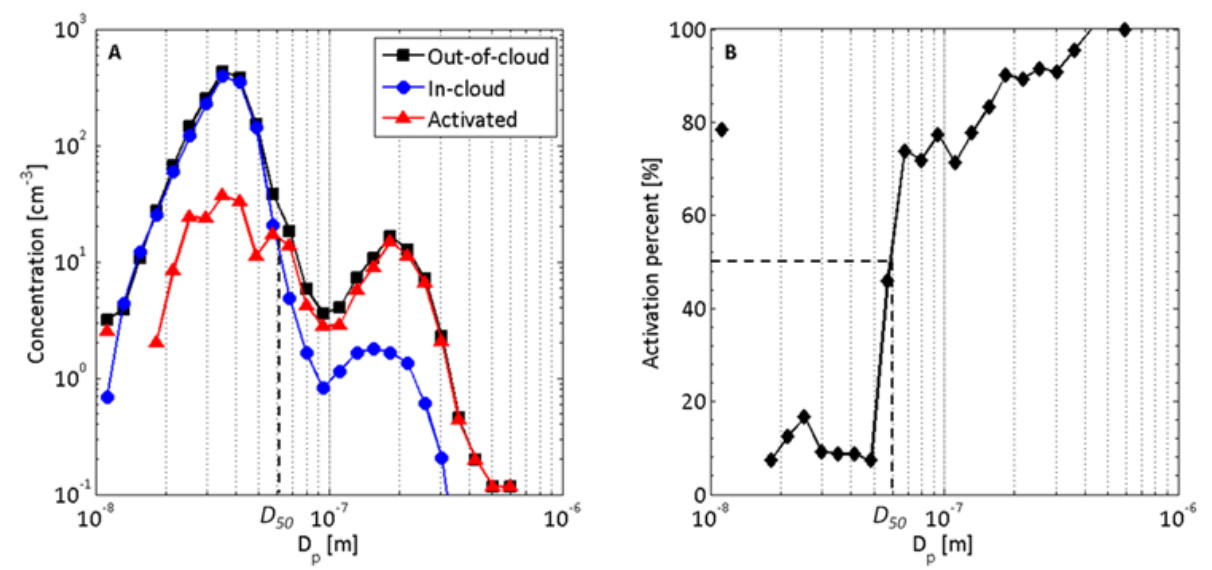

Fig. 16. Median size distributions of out-of-cloud, in-cloud and activated particles (A) and activation percent as a function of particle size (B). The dashed lines show the activation diameter $D_{50}$ (out-of-cloud minus in-cloud size spectra). Out-of-cloud and in-cloud size distributions are medians over corresponding times. Activation percent $(\mathbf{B})$ is defined as activated divided by in-cloud size spectra.

A demonstration of the aerosol-cloud interaction of the newly found aerosol source was seen when the station was inside a cloud three times during the last NPF event period. We observed cloud droplet activation of particles only a few hours after they had formed in blue-ice and mountainous areas. Due to low concentrations of accumulation mode particles, the activation diameter was very low $(60 \mathrm{~nm})$ and some activation occurred already at $48 \mathrm{~nm}$-sized particles. This shows that if there are enough oxidised organics in the atmosphere, particles in the Antarctic atmosphere do not have to grow over several days before they can reach climatically relevant sizes.

This is the first time that freshwater vegetation has been identified as an aerosol precursor source. In the future when the climate warms, the area of meltwater ponds and biogenic activity in such ponds are likely to increase (Liston et al., 1999), so we anticipate that the new aerosol source identified here and its climatic role will also grow in importance. Currently as much as $11.8 \%$ of the Antarctic continent experiences surface melting (Liston and Winther, 2005). It could 


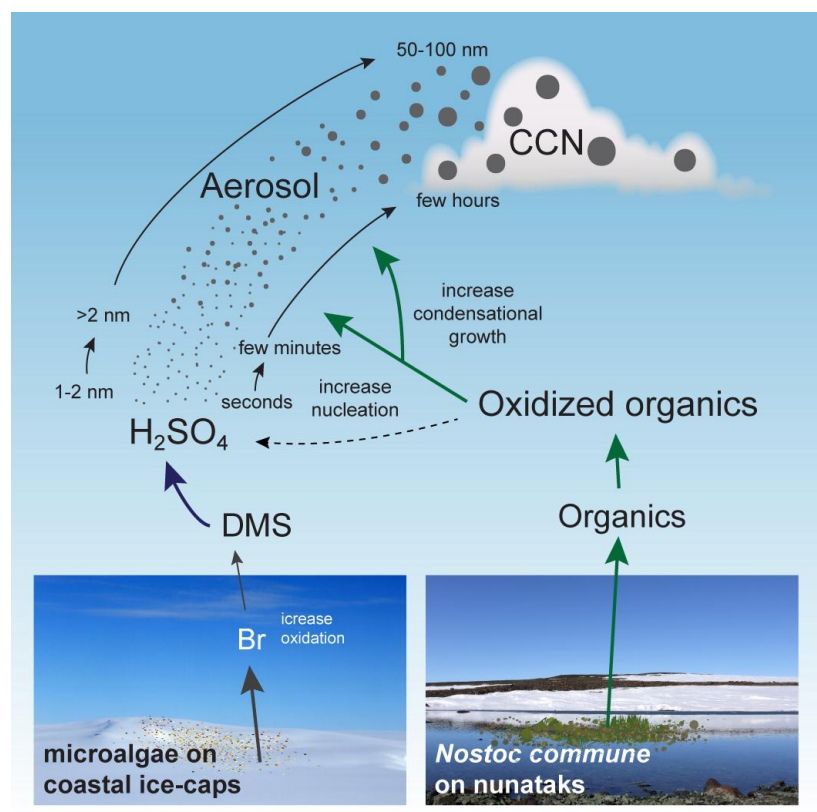

Fig. 17. Continental new particle formation in Antarctica: meltwater ponds that form during summertime hold lots of organics inside including blue-green algae Nostoc commune. These ponds are found close to nunataks and blue-ice areas. The organics are oxidised in the atmosphere and increase locally the condensational growth of particles and can have an influence in the nucleation as well. The oxidised organics play a key role in growing the aerosols enough - up to 50-100 nm in diameter - for them to have climatic effects. This growth takes only few hours, whereas with only sulphuric acid growing the particles, the timescale would be days and the particles would be scavenged from the atmosphere before reaching sufficient sizes. The bromine emissions from coastal ice caps, as suggested by Antony et al. (2010), increase the oxidation of DMS and can therefore increase the nucleation even at larger scales.

be noted that dramatic changes in the open-water period, Chlorophyll $a$ concentrations and water temperature have already been observed at Signy Island (Quayle et al., 2002). Besides Antarctica, a similar process is expected to occur in the Arctic atmosphere, especially at locations having conditions similar to our site, such as the coastal areas of Greenland, Svalbard and Canadian High Arctic.

Acknowledgements. We thank Pasi P. Aalto, Erkki Siivola, Jani Hakala, Teemu Mäkelä, Riikka Väänänen and Tuukka Petäjä for their technical support before the expedition, Quynh Nguyen for the help in the chemistry laboratory and Kari Hartonen for his expertise. We also thank the accredited calibration laboratory at the Finnish Meteorological Institute for the calibration of the ozone analyser before the expedition. We are grateful for the Academy of Finland (project no. 127534 and 128731), the Academy of Finland Centre of Excellence program (project no. 1118615), European Research Council (project no. 227463-ATMNUCLE) and the Nordic Centre of Excellence CRAICC (Cryosphere-atmosphere interactions in a changing Arctic climate) for funding. We also wish to express our gratitude to FINNARP for their excellent logistic support.

Edited by: A. Stohl

\section{References}

Aalto, P., Hämeri, K., Becker, E., Weber, R., Salm, J., Mäkelä, J., Hoell, C., O’Dowd, C. D., Karlsson, H., Hansson, H.-C., Väkevä, M., Koponen, I. K., Buzorius, G., and Kulmala M.: Physical characterization of aerosol particles during nucleation events, Tellus, 53B, 344-358, 2001.

Antony R., Thamban, M., Krishnan, K. P., and Mahalinganathan, K.: Is cloud seeding in coastal Antarctic linked to bromine and nitrate variability in snow?, Environ. Res. Lett., 5, 014009, doi:10.1088/1748-9326/5/1/014009, 2010.

Anttila, T., Vaattovaara, P., Komppula, M., Hyvärinen, A.-P., Lihavainen, H., Kerminen, V.-M., and Laaksonen, A.: Sizedependent activation of aerosols into cloud droplets at a subarctic background site during the second Pallas Cloud Experiment (2nd PaCE): method development and data evaluation, Atmos. Chem. Phys., 9, 4841-4854, doi:10.5194/acp-9-4841-2009, 2009.

Asmi, E., Frey, A., Virkkula, A., Ehn, M., Manninen, H. E., Timonen, H., Tolonen-Kivimäki, O., Aurela, M., Hillamo, R., and Kulmala, M.: Hygroscopicity and chemical composition of Antarctic sub-micrometre aerosol particles and observations of new particle formation, Atmos. Chem. Phys., 10, 4253-4271, doi:10.5194/acp-10-4253-2010, 2010.

Brandt, R. and Warren, S.: Solar-heating rates and temperature profiles in Antarctic snow and ice, J. Glaciol., 39, 99-110, 1993.

Broady, P. A.: Broadscale patterns in the distribution of aquatic and terrestrial vegetation at three ice-free regions on Ross Island, Antarctica, Hydrobiologia, 127, 77-95, 1989.

Broady, P. A.: Diversity, distribution and dispersal of Antarctic terrestrial algae, Biodivers. Conserv., 5, 1307-1335, 1996.

Chen, J. L., Wilson, C. R., Blankenship, D., and Tapley, B. D.: Accelerated Antarctic ice loss from satellite gravity measurements, Nat. Geosci., 2, 859-862, 2009.

Dal Maso, M., Kulmala, M., Lehtinen, K. E. J., Mäkelä, J. M., Aalto, P., and O'Dowd, C. D.: Condensation and coagulation sinks and formation of nucleation mode particles in coastal and boreal forest boundary layers, J. Geophys. Res., 107, 8097, doi:10.1029/2001JD001053, 2002.

Dal Maso, M., Kulmala, M., Riipinen, I., Wagner, R., Hussein T., Aalto, P. P., and Lehtinen, K. E. J.: Formation and growth of fresh atmospheric aerosols: eight years of aerosol size distribution data from SMEAR II, Hyytiälä, Finland, Boreal Environ. Res., 10, 323-336, 2005.

Dal Maso, M., Sogacheva, L., Aalto, P. P., Riipinen, I., Komppula, M., Tunved, P., Korhonen, L., Suur-Uski, V., Hirsikko, A., Kurtén, T., Kerminen, V.-M., Lihavainen, H., Viisanen, Y., Hansson, H.-C., and Kulmala, M.: Aerosol size distribution measurements at four Nordic field stations: identification, analysis and trajectory analysis of new particle formation bursts, Tellus B, 59, 350-361, 2007.

Davis, D., Chen, G., Kasibhatla, P., Jefferson, A., Tanner, D., Eisele, F., Lenschow, D., Neff and Berresheim, H.: DMS oxidation in the Antarctic marine boundary layer: Comparison of model simulations and field observations of DMS, DMSO, $\mathrm{DMSO}_{2}$, 
$\mathrm{H}_{2} \mathrm{SO}_{4}(\mathrm{~g}), \mathrm{MSA}(\mathrm{g})$ and MSA(p), J. Geophys. Res., 103, 16571678, 1998.

Dodds, W. K., Gudder, D. A., and Mollenhauer, D.: The Ecology of Nostoc, J. Phycol., 31, 2-18, 1995.

Draxler, R. R. and Rolph, G. D.: HYSPLIT (HYbrid Single-Particle Lagrangian Integrated Trajectory) Model access via NOAA ARL READY Website, http://ready.arl.noaa.gov/HYSPLIT.php (last access: 14 August 2012), NOAA Air Resources Laboratory, Silver Spring, MD, 2012.

Ehn, M., Kleist, E., Junninen, H., Petäjä, T., Lönn, G., Schobesberger, S., Dal Maso, M., Trimborn, A., Kulmala, M., Worsnop, D. R., Wahner, A., Wildt, J., and Mentel, Th. F.: Gas phase formation of extremely oxidized pinene reaction products in chamber and ambient air, Atmos. Chem. Phys., 12, 5113-5127, doi:10.5194/acp-12-5113-2012, 2012.

Fiebig, M., Lunder, C. R., and Stohl, A.: Tracing biomass burning aerosol from South America to Troll Research Station, Antarctica, Geophys. Res. Lett., 36, L14815, doi:10.1029/2009GL038531, 2009.

González-Toril, E., Amils, R., Delmas, R. J., Petit, J.-R., Komárek, J., and Elster, J.: Bacterial diversity of autotrophic enriched cultures from remote, glacial Antarctic, Alpine and Andean aerosol, snow and soil samples, Biogeosciences, 6, 33-44, doi:10.5194/bg-6-33-2009, 2009.

Hall, A.: The Role of Surface Albedo Feedback in Climate, J. Climate, 17, 1550-1568, 2004.

Hara, K., Osada, K., Nishita-Hara, C., Yabuki, M., Hayashi, M., Yamanouchi, T., Wada, M., and Shiobara, M.: Seasonal features of ultrafine particle volatility in the coastal Antarctic troposphere, Atmos. Chem. Phys., 11, 9803-9812, doi:10.5194/acp-11-98032011, 2011.

Hirsikko, A., Laakso, L., Hõrrak, U., Aalto, P. P., Kerminen, V.M., and Kulmala, M.: Annual and size dependent variation of growth rates and ion concentrations in boreal forest, Boreal Environ. Res., 10, 357-369, 2005.

Holm-Hansen, O.: Isolation and Culture of Terrestrial and Freshwater Algae of Antarctica, Phycologia, 4, 43-51, 1964.

Ito, T.: Size distribution of Antarctic submicron aerosols, Tellus, 45B, 145-159, 1993.

Jefferson, A., Tanner, D., Eisele, F., and Berresheim, H, Sources and sinks of $\mathrm{H}_{2} \mathrm{SO}_{4}$ in the remote Antarctic marine boundary layer, J. Geophys. Res., 103, 1639-1645, doi:10.1029/97JD01212, 1998a.

Jefferson, A., Tanner, D., Eisele, F., Davis, D., Chen, G., Crawford, J., Huey, J., Torres, A., and Berresheim, H.: OH photochemistry and methane sulfonic acid formation in the coastal Antarctic boundary layer, J. Geophys. Res., 103, 1647-1656, doi:10.1029/97JD02376, 1998b,

Johansson, P. and Thor, G.: Lichen species density and abundance over ten years in permanent plots in inland Dronning Maud Land, Antarctica, Antarct. Sci., 20, 115-121, 2008.

Kallio, M., Jussila, M., Rissanen, T., Anttila, P., Hartonen, K., Reissell, A., Vreuls, R., Adahchour, M., and Hyötyläinen, T.: Comprehensive two-dimensional gas chromatography coupled to time-of-flight mass spectrometry in the identification of organic compounds in atmospheric aerosols from coniferous forest, J. Chromatogr. A, 1125, 234-243, 2006.

Kerminen, V.-M., Lihavainen, H., Komppula, M., Viisanen, Y., and Kulmala, M.: Direct observational evidence linking atmospheric aerosol formation and cloud droplet activation, Geophys. Res. Lett., 32, L14803, doi:10.1029/2005GL023130, 2005.

Komppula, M., Lihavainen, H., Kerminen, V.-M., Kulmala, M., and Viisanen, Y.: Measurements of cloud droplet activation of aerosol particles at a clean subarctic background site, J. Geophys. Res., 110, D06204, doi:10.1029/2004JD005200, 2005.

Koponen, I. K., Virkkula, A., Hillamo, R., Kerminen, V.-M., and Kulmala, M.: Number size distributions and concentrations of the continental summer aerosols in Queen Maud Land, Antarctica, J Geophys. Res., 108, 4587, doi:10.1029/2003JD003614, 2003.

Korhonen, H., Carslaw, K. S., Spracklen, D. V., Mann, G. W., and Woodhouse, M. T.: Influence of oceanic dimethyl sulfide emissions on cloud condensation nuclei concentrations and seasonality over the remote Southern Hemisphere oceans: A global model study, J. Geophys. Res., 113, D15204, doi:10.1029/2007JD009718, 2008.

Kulmala, M., Dal Maso, M., Mäkelä, J. M., Pirjola, L., Väkevä, M., Aalto, P., Miikkulainen, P., Hämeri, K., and O’Dowd, C. D.: On the formation, growth and composition of nucleation mode particles, Tellus, 53B, 479-490, 2001.

Kulmala, M., Vehkamäki, H., Petäjä, T., Dal Maso, M., Lauri, A., Kerminen, V.-M., Birmili, W., and McMurry, P. H.: Formation and growth rates of ultrafine atmospheric particles: a review of observations, J. Aerosol Sci., 35, 143-176, 2004.

Kulmala, M., Riipinen, I., Sipilä, M., Manninen, H. E., Petäjä, T., Junninen, H., Dal Maso, M., Mordas, G., Mirme, A., Vana, M., Hirsikko, A., Laakso, L., Harrison, R. M., Hanson, I., Leung, C., Lehtinen, K. E. J., and Kerminen, V.-M.: Toward Direct Measurement of Atmospheric Nucleation, Science, 318, 89-92, doi:10.1126/science.1144124, 2007.

Kulmala, M., Petäjä, T., Nieminen, T., Sipilä, M., Manninen, H. E., Lehtipalo, K., Dal Maso, M., Aalto, P. P., Junninen, H., Paasonen, P., Riipinen, I., Lehtinen, K. E. J., Laaksonen, A., and Kerminen, V.-M.: Measurement of the nucleation of atmospheric aerosol particles, Nat. Protoc., 7, 1651-1667, 2012.

Lehtinen A. and Luttinen, A.: Chemical constraints of the influence of subsurface and surface melting on Lake Basen, Western Dronning Maud Land, Antarctica, Quaternary studies in the northern and Arctic regions of Finland, Geological Survey of Finland, Special Paper 40, 123-130, 2005.

Lehtinen, K. E. J., Dal Maso, M., Kulmala, M., and Kerminen, V.M.: Estimating nucleation rates from apparent particle formation rates and vice versa: Revised formulation of the KerminenKulmala equation, J. Aerosol Sci., 38, 988-994, 2007.

Liengen, T. and Olsen, R. A.: Nitrogen Fization by Free-living Cyanobacteria from Different Coastal Sites in a High Arctic Tundra, Spitsbergen, Arctic Alpine Res., 29, 470-477, 1997.

Lihavainen, H., Komppula, M., Kerminen, V.-M., Järvinen, H., Viisanen, Y., Lehtinen, K., Vana, M., and Kulmala, M.: Size distributions of atmospheric ions inside clouds and in cloud-free air at a remote continental site, Boreal Environ. Res., 12, 337-344, 2007.

Lihavainen, H., Kerminen, V.-M., Komppula, M., Hyvärinen, A.-P., Laakia, J., Saarikoski, S., Makkonen, U., Kivekäs, N., Hillamo, R., Kulmala, M., and Viisanen, Y.: Measurements of the relation between aerosol properties and microphysics and chemistry of low level liquid water clouds in Northern Finland, Atmos. Chem. Phys., 8, 6925-6938, doi:10.5194/acp-8-6925-2008, 2008. 
Liston, G. E. and Winther, J.-G.: Antarctic Surface and Subsurface Snow and Ice Melt Fluxes, J. Climate, 18, 1469-1481, 2005.

Liston, G. E., Bruland, O., Winther, J.-G., Elvehøy, H., and Sand, K.: Meltwater production in Antarctic blue-ice areas: sensitivity to changes in atmospheric forcing, Pol. Rec., 18, 283-290, 1999.

Mäkelä, J. M., Riihelä, M., Ukkonen, A., Jokinen, V., and Keskinen, J.: Comparison of mobility equivalent diameter with KelvinThomson diameter using ion mobility data, J. Chem. Phys., 105, 1562-1571, 2006.

Manninen, H. E., Nieminen, T., Asmi, E., Gagné, S., Häkkinen, S., Lehtipalo, K., Aalto, P., Vana, M., Mirme, A., Mirme, S., Hõrrak, U., Plass-Dülmer, C., Stange, G., Kiss, G., Hoffer, A., Törő, N., Moerman, M., Henzing, B., de Leeuw, G., Brinkenberg, M., Kouvarakis, G. N., Bougiatioti, A., Mihalopoulos, N., O'Dowd, C., Ceburnis, D., Arneth, A., Svenningsson, B., Swietlicki, E., Tarozzi, L., Decesari, S., Facchini, M. C., Birmili, W., Sonntag, A., Wiedensohler, A., Boulon, J., Sellegri, K., Laj, P., Gysel, M., Bukowiecki, N., Weingartner, E., Wehrle, G., Laaksonen, A., Hamed, A., Joutsensaari, J., Petäjä, T., Kerminen, V.-M., and Kulmala, M.: EUCAARI ion spectrometer measurements at 12 European sites - analysis of new particle formation events, Atmos. Chem. Phys., 10, 7907-7927, doi:10.5194/acp-10-79072010, 2010.

Mauldin, R. L., Kosciuch, E., Henry, B., Eisele, F., Shetter, R., Lefer, B., Chen, G., Davis, D., Bandy, A., and Thornton, D.: Measurements of $\mathrm{OH}, \mathrm{HO}_{2}+\mathrm{RO}_{2}, \mathrm{H}_{2} \mathrm{SO}_{4}$, and MSA at the South Pole during ISCAT 2000, Atmos. Environ., 38, 54235437, 2004.

Mauldin R., Kosciuch, E., Eisele, F., Huey, G., Tanner, D., Sjostedt, S., Blake, D., Chen, G., Crawford, J., and Davis, D.: South Pole Antarctica observations and modeling results: New insights on HOX radical and sulfur chemistry, Atmos. Environ., 44, 572581,2010

McFiggans, G., Artaxo, P., Baltensperger, U., Coe, H., Facchini, M. C., Feingold, G., Fuzzi, S., Gysel, M., Laaksonen, A., Lohmann, U., Mentel, T. F., Murphy, D. M., O’Dowd, C. D., Snider, J. R., and Weingartner, E.: The effect of physical and chemical aerosol properties on warm cloud droplet activation, Atmos. Chem. Phys., 6, 2593-2649, doi:10.5194/acp-6-2593-2006, 2006.

McMurry, P. H. and Friedlander, S. K.: New particle formation in the presence of an aerosol, Atmos. Environ., 13, 1635-1651, 1979.

Mirme, A., Tamm, E., Mordas, G., Vana, M., Uin, J., Mirme, S., Bernotas, T., Laakso, L., Hirsikko, A., and Kulmala, M.: A Widerange multi-channel Air Ion Spectrometer, Boreal Environ. Res., 12, 247-264, 2007.

Moorhead, D. L., Davis, W. S., and Wharton, R. A.: Carbon dynamics of aquatic microbial mats in the Antarctic dry valleys: a modeling synthesis, in: Ecosystem Processes in Antarctic Icefree Landscapes, edited by: Lyons, W. B., Howard-Williams, C., and Hawes, I., Balkema, Rotterdam, the Netherlands, 181-196, 1997.

Nieminen, T., Lehtinen, K. E. J., and Kulmala, M.: Sub-10 nm particle growth by vapor condensation - effects of vapor molecule size and particle thermal speed, Atmos. Chem. Phys., 10, 97739779, doi:10.5194/acp-10-9773-2010, 2010.

Novis, P. M. and Smissen, R. D.: Two genetic and ecological groups of Nostoc commune in Victoria Land, Antarctica, revealed by AFLP analysis, Antarct. Sci., 18, 573-581, 2006.
Novis, P. M., Whitehead, D., Gregorich, E. G., Hunt, J. E., Sparrow, A. D., Hopkins, D. W., Elberling, B., and Greenfield, L. G.: Annual carbon fixation in terrestrial populations of Nostoc commune (Cyanobacteria) from an Antarctic dry valley is driven by temperature regime, Glob. Change Biol., 13, 1224-1237, 2007.

O’Dowd, C. D., Lowe, J., Smith, M. H., Davison, B., Hewitt, C. N., and Harrison, R. M.: Biogenic sulphur emissions and inferred non-sea-salt-sulphate cloud condensation nuclei in and around Antarctica, J. Geophys. Res., 102, 12839-12854, 1997.

O’Dowd, C. D., Hämeri, K., Mäkelä, J. M., Pirjola, L., Kulmala, M., Jennings, S. G., Berresheim, H., Hansson, H.-C., de Leeuw, G., Kunz, G. J., Allen, A. G., Hewitt, N., Jackson, A., Viisanen, Y., and Hoffmann, T.: A dedicated study of New Particle Formation and Fate in the Coastal Environment (PARFORCE): overview of objectives and achiements, J. Geophys. Res., 107, 8108, doi:10.1029/2001JD000555, 2002.

Paasonen, P., Nieminen, T., Asmi, E., Manninen, H. E., Petäjä, T., Plass-Dülmer, C., Flentje, H., Birmili, W., Wiedensohler, A. Hõrrak, U., Metzger, A., Hamed, A., Laaksonen, A., Facchini, M. C., Kerminen, V.-M., and Kulmala, M.: On the roles of sulphuric acid and low-volatility organic vapours in the initial steps of atmospheric new particle formation, Atmos. Chem. Phys., 10, 11223-11242, doi:10.5194/acp-10-11223-2010, 2010.

Park, J., Sakurai, H., Vollmers, K., and McMurry, P. H.: Aerosol size distributions measured at the South Pole during ISCAT, Atmos. Environ., 38, 5493-5500, 2004.

Pierce, J. R., Riipinen, I., Kulmala, M., Ehn, M., Petäjä, T., Junninen, H., Worsnop, D. R., and Donahue, N. M.: Quantification of the volatility of secondary organic compounds in ultrafine particles during nucleation events, Atmos. Chem. Phys., 11, 9019 9036, doi:10.5194/acp-11-9019-2011, 2011.

Pritchard, H. D., Arthern, R. J., Vaughan, D. G., and Edwards, L. A.: Extensive dynamic thinning on the margins of the Greenland and Antarctic ice sheets, Nature, 461, 971-975, 2009.

Quayle W. C., Peck, L. S., Peat, H., Ellis-Evans, J. C., and Harrigan, P. R.: Extreme Responses to Climate Change in Antarctic Lakes, Science, 295, 5555, doi:10.1126/science.1064074, 2002.

Rignot, E., Casassa, G., Gogineni, P., Krabill, W., Rivera, A., and Thomas, R.: Accelerated ice discharge from the Antarctic Peninsula following the collapse of Larsen B ice shelf, Geophys. Res. Lett., 31, L18401, doi:10.1029/2004GL020697, 2004.

Riipinen, I., Pierce, J. R., Yli-Juuti, T., Nieminen, T., Häkkinen, S., Ehn, M., Junninen, H., Lehtipalo, K., Petäjä, T., Slowik, J., Chang, R., Shantz, N. C., Abbatt, J., Leaitch, W. R., Kerminen, V.-M., Worsnop, D. R., Pandis, S. N., Donahue, N. M., and Kulmala, M.: Organic condensation: a vital link connecting aerosol formation to cloud condensation nuclei (CCN) concentrations, Atmos. Chem. Phys., 11, 3865-3878, doi:10.5194/acp-11-38652011, 2011.

Ruiz-Jimenez, J., Parshintsev, J., Laitinen, T., Hartonen, K., Riekkola, M.-L., Petäjä, T., Virkkula, A., and Kulmala, M.: A Complete Methodology for the Reliable Collection, Sample Preparation, Separation and Determination of Organic Compounds in Ultrafine $30 \mathrm{~nm}, 30 \mathrm{~nm}$ and $50 \mathrm{~nm}$ Atmospheric Aerosol Particles, Anal. Methods, 3, 2501-2509, 2011a.

Ruiz-Jimenez, J., Parshintsev, J., Laitinen, T., Hartonen, K., Riekkola, M.-L., Petäjä, T., and Kulmala, M.: Comprehensive two-dimensional gas chromatography, a valuable technique for screening and semiquantitation of different chemical compounds 
in ultrafine $30 \mathrm{~nm}$ and $50 \mathrm{~nm}$ aerosol particles, J. Environ. Monit., 13, 2994-3003, 2011b.

Schlicting, H. E., Speziale, B. J., and Zink, R. M.: Dispersal of algae and Protozoa by Antarctic flying birds, Antarct. J. US, 13, 147149, 1978.

Schneider, D. P., Deser, C., and Okumura, Y.: An Assessment and interpretation of the observed warming of West Antarctica in the austral spring, Clim. Dynam., 38, 323-347, doi:10.1007/s00382010-0985-x, 2012.

Shaw, G. E.: Antarctic aerosols: a review, Rev. Geophys., 26, 89$112,1988$.

Sheath, R. G., Vis, M. L., Hambrook, J. A., and Cole, K. M.: Tundra stream macroalgae of North America: composition, distribution and physiological adaptations, Hydrobiologia, 336, 67-82, 1996.

Sohlenius, B., Boström, S., and Jönsson, I.: Occurrence of nematodes, tardigrades and rotifers on ice-free areas in East Antarctica, Pedobiologia, 48, 395-408, 2004.

Steig, E. J., Schneider, D. P., Rutherford, S. D., Mann, M. E., Comiso, J. C., and Shindell, D. T.: Warming of the Antarctic ice-sheet surface since the 1957 International Geophysical Year, Nature, 457, 459-462, 2009.

Struthers, H., Ekman, A. M. L., Glantz, P., Iversen, T., Kirkevåg, A., Mårtensson, E. M., Seland, Ø., and Nilsson, E. D.: The effect of sea ice loss on sea salt aerosol concentrations and the radiative balance in the Arctic, Atmos. Chem. Phys., 11, 3459-3477, doi:10.5194/acp-11-3459-2011, 2011.

Weller, R., Wagenbach, D., Legrand, M., Elsässer, C., Tian-Kunze, X., and König-Langlo, G.: Continuous 25-yr aerosol records at coastal Antarctica - I: inter-annual variability of ionic compounds and links to climate indices, Tellus, 63B, 901-919, 2011.

Wharton Jr., R. A., Parker, B. C., and Simmons Jr., G. M.: Distribution, species composition and morphology of algal mats in Antarctic dry valley lakes, Phycologia, 22, 355-365, 1983.

Vincent, W. F. and Howard-Williams, C.: Antarctic stream ecosystems: physiological ecology of a blue green algal epilithon, Freshwater Biol., 16, 219-233, 1986.

Vincent, W. F. and Howard-Williams, C.: Microbial communities in southern Victoria Land streams (Antarctica) II. The effects of low temperature, Hydrobiologia, 172, 39-49, 1989.
Virkkula, A., Teinilä, K., Hillamo, R., Kerminen, V.-M., Saarikoski, S., Aurela, M., Viidanoja, J., Paatero, J., Koponen, I. K., and Kulmala, M.: Chemical composition of boundary layer aerosol over the Atlantic Ocean and at an Antarctic site, Atmos. Chem. Phys., 6, 3407-3421, doi:10.5194/acp-6-3407-2006, 2006.

Virkkula, A., Hirsikko, A., Vana, M., Aalto, P. P., Hillamo, R., and Kulmala, M.: Charged particle size distributions and analysis of particle formation events at the Finnish Antarctic research station, Boreal Environ. Res., 12, 397-408, 2007.

Virkkula, A., Asmi, E., Teinilä, K., Frey, A., Aurela, M., Timonen, H., Mäkelä, T., Samuli, A., Hillamo, R., Aalto, P. P., Kirkwood, S., and Kulmala, M.: Review of Aerosol Research at the Finnish Antarctic Research Station Aboa and its Surroundings in Queen Maud Land, Antarctica, Geophysica, 45, 163-181, 2009.

Yli-Juuti, T., Riipinen, I., Aalto, P. P., Nieminen, T., Maenhaut, W., Janssens, I. A., Claeys, M., Salma, I., Ocskay, R., Hoffer, A., Imre, K., and Kulmala, M.: Characteristics of new particle formation events and cluster ions at K-puszta, Hungary, Boreal Environ. Res., 14, 683-698, 2009.

Yli-Juuti, T., Nieminen, T., Hirsikko, A., Aalto, P. P., Asmi, E., Hõrrak, U., Manninen, H. E., Patokoski, J., Dal Maso, M., Petäjä, T., Rinne, J., Kulmala, M., and Riipinen, I.: Growth rates of nucleation mode particles in Hyytiälä during 20032009: variation with particle size, season, data analysis method and ambient conditions, Atmos. Chem. Phys., 11, 12865-12886, doi:10.5194/acp-11-12865-2011, 2011.

Yu, F. and Luo, G.: Ocean Dimethyl Sulfide Emissions and New Particle Formation around the Coast of Antarctica: A Modeling Study of Seasonal Variations and Comparison with Measurements, Atmosphere, 1, 34-50, 2010

Yu, F., Wang, Z., Luo, G., and Turco, R.: Ion-mediated nucleation as an important global source of tropospheric aerosols, Atmos. Chem. Phys., 8, 2537-2554, doi:10.5194/acp-8-2537-2008, 2008. 